\title{
森林の展望 4
}

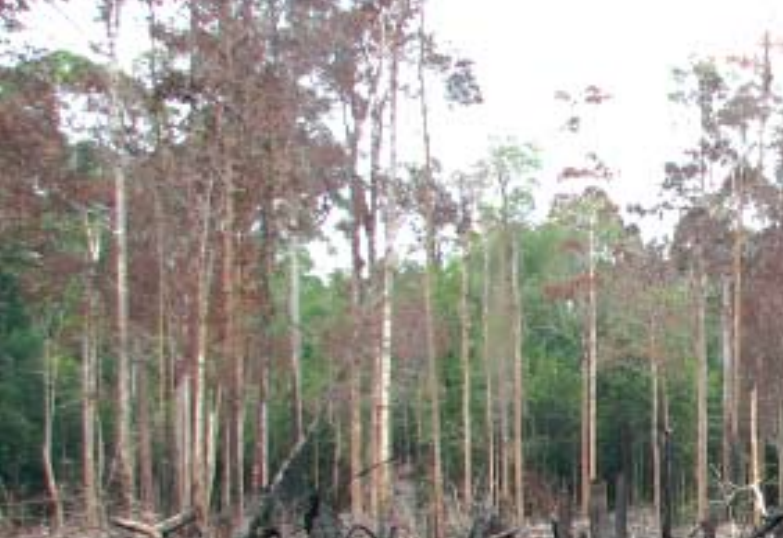

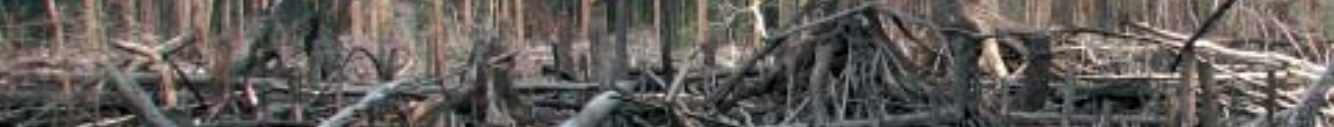

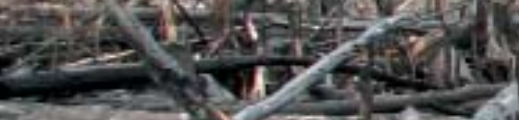
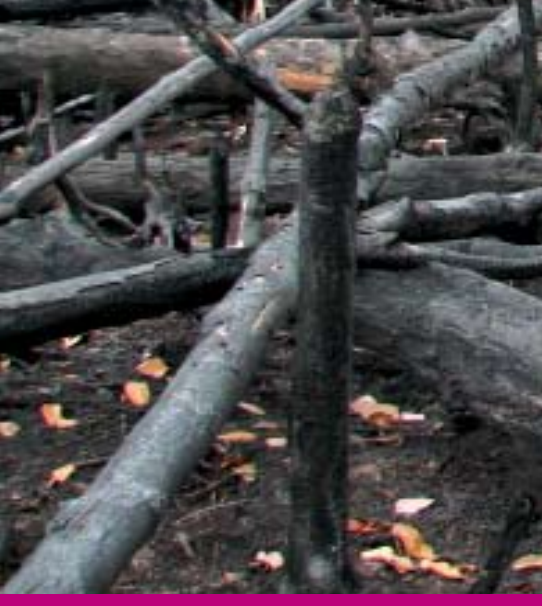

木はお金で育つか?

「森林減少と森林劣化に由来する排出削減(REDD)」

に対する森林減少研究からの示唆

マルク・カンニネン

ダニエル・ムルディアルソ

フランシス・セイモア

アリッド・アンジェルソン

スウェン・ワンダー

ローラ・ジャーマン

共著

藤間 剛

鷹尾元

御田成顕

岩永青史

共訳 
国際林業研究センター

(The Center for International Forestry Research , CIFOR)

国際林業研究センターは、森林減少及び森林劣化の社会的、経済的、環境的影響に対する世界 的な懸念の高まりをうけ、1993年に設立された。CIFORは、森林に依存して暮らす人々の福祉を 向上させ、また、熱帯諸国が将来にわたって森林資源から便益を受けることができるよう、適切 な情報と森林管理手法を提供することを目的に研究活動を実施している。CIFORは数百にのぼ る研究パートナーと協力し24力国以上で研究を行い、その設立以来、世界レベル・国家レベル での森林政策の改善のための提言を行う役を担っている。

CIFORは、国際農業研究協議グループ(Consultative Group on International Agricultural Research, CGIAR)の15センターの一つである。インドネシアのボゴールの本部とともに、 CIFORはブラジル、ボリビア、ブルキナファソ、カメルーン、エチオピア、インド、ザンビア、ジンバブ エに事務所をもち、世界の30を越える国々で活動している。

ドナー

CIFORは、国家政府機関、国際開発機関、民間財団、地域組織機関などから、主要な活動資 金供与を受けています。2006年にCIFORは次の組織・機関から活動資金の供与を受けま した。Australia, Asian Development Bank (ADB), African Wildlife Foundation, Belgium, Canada, Carrefour, Cecoforma, China, Centre de coopération internationale en recherche agronomique pour le développement (CIRAD), Convention on Biological Diversity, Cordaid, Conservation International Foundation (CIF), European Commission, Finland, Food and Agriculture Organization of the United Nations (FAO), Ford Foundation, France, German Agency for Technical Cooperation (GTZ), German Federal Ministry for Economic Cooperation and Development (BMZ), German Foundation for International Cooperation, Global Forest Watch, Indonesia, Innovative Resource Management (IRM), International Institute for Environment and Development, International Development Research Centre (IDRC), International Fund for Agricultural Development (IFAD), International Tropical Timber Organization (ITTO), Israel, Italy, the World Conservation Union (IUCN), Japan, Korea, MacArthur Foundation, Netherlands, Norway, Netherlands Development Organization, Overseas Development Institute (ODI), Peruvian Secretariat for International Cooperation (RSCI), Philippines, Spain, Sweden, Swedish University of Agricultural Sciences (SLU), Switzerland, The Overbrook Foundation, The Tinker Foundation Incorporated, The Nature Conservancy (TNC), Tropical Forest Foundation, Tropenbos International, United States, United Kingdom, United Nations Environment Programme (UNEP), United Nations Educational, Scientific and Cultural Organization (UNESCO), United Nations Forum on Forests (UNFF), Wageningen International, World Bank, World Resources Institute (WRI) and World Wide Fund for Nature (WWF). 


\section{木はお金で育つか?}

「森林減少と森林劣化に由来する排出削減 (REDD)」 に対する森林減少研究からの示唆

$$
\begin{aligned}
& \text { マルク・カンニネン } \\
& \text { ダニエル・ムルディアルソ } \\
& \text { フランシス・セイモア } \\
& \text { アリッド・アンジェルソン } \\
& \text { スウェン・ワンダー } \\
& \text { ローラ・ジャーマン }
\end{aligned}
$$

共著

$$
\begin{aligned}
& \text { 藤間 剛 } \\
& \text { 鷹尾 元 } \\
& \text { 御田成顕 } \\
& \text { 岩永青史 } \\
& \text { 共訳 }
\end{aligned}
$$


Kanninen, M. et al.

Do trees grow on money? The implications of deforestation research for policies to promote REDD/by Markku Kanninen, Daniel Murdiyarso, Frances Seymour, Arild Angelsen, Sven Wunder, Laura German. Bogor, Indonesia: Center for International Forestry Research (CIFOR), 2007.

藤間 剛 ((独)森林総合研究所)

鷹尾 元(国際林業研究センター(CIFOR))

御田成顕(ボゴール農科大学森林科学研究科)

岩永青史(筑波大学生命環境科学研究科)

共訳

木はお金で育つか?「森林減少と森林劣化に由来する排出削減(REDD)」に対す る森林減少研究からの示唆

ISBN 978-979-1412-57-5

viii+79p.

CABI thesaurus: 1 . deforestation 2. forests 3. degradation 4. causes 5. carbon 6. emission 7. carbon sequestration 8. international 9. policy 10. governance 11. climatic change 12 . environmental

写真説明:

表紙 - モノカルチャーのゴム農園造成のため数千へクタールの泥炭林が伐り開 かれ焼かれている(インドネシア、西カリマンタン州ダナウセンタルム国立公園、 Leon Budi Prasetyo撮影)

3頁 - インドネシア、パプア州、Mamberamo Basin の低地熱帯雨林(Daniel Murdiyarso撮影)

4頁 - フランス領ギアナでの択伐(Douglas Sheil 撮影)

14頁 - 収穫されたパルプ材の積み込み(インドネシア、リアウ州、Widya

Prajanthi 撮影)

31頁 - 中国九寨溝の山地混交林(Daniel Murdiyarso撮影)

44頁 - アカシアマンギウム植林地のための泥炭地域の排水(インドネシア、リア

ウ州、Daniel Murdiyarso撮影)

52頁 - シェラバターノキ(Vitellaria paradoxa)が優占する乾燥林(ブルキナファ ソ、Sapouy、 Daniel Murdiyarso撮影)

\section{(c) 2008 by CIFOR}

All rights reserved. Published in 2008

Printed by Harapan Prima, Jakarta

Published by Center for International Forestry Research

J1. CIFOR, Situ Gede, Bogor Barat 16115, Indonesia

Tel.: +62 (251) 622622; Fax: +62 (251) 622100

E-mail: cifor@cgiar.org

Web site: http://www.cifor.cgiar.org 


\section{目次}

序文 iv

謝辞 vi vi

要旨 vii

1. 序論 1

2. 森林減少についてわかっていること 5

2.1 最近の減少速度についての概観 5

2.2 森林推移 10

2.3 将来のREDD制度に対する示唆 10

3. 森林減少と森林劣化の直接的および潜在的な原因 15

3.1 定義と区別 15

3.2 森林減少と森林劣化の直接的原因 17

3.3 森林減少と森林劣化の潜在的原因 21

3.4 将来のREDD制度に対する示唆 27

4. 森林減少と劣化の削減のための政策選択 29

4.1 経済・財政的手段 30

4.2 直接的な規制 37

4.3 統治機構と組織的能力の強化 39

4.4 将来のREDD制度に対する示唆 42

5. REDD支持政策と今後の研究に対する示唆 45

5.1 森林炭素観測と基準值(ベースライン) 46

5.2 政策的選択肢 47

5.3 制度と統治の必要性 49

引用文献 53

付録-POLEX日本語版で紹介された本書の引用文献 63 


\section{序文}

森林は現在、1992年のリオ地球サミット以来見られなかったレベルの国際的 な注目を集めている。2006年のスターン報告書と気候変動にともなう経済損失 に関する冷静な予測は、森林と気候の間の重要な関係を政策立案者に再認識 させるのに説得力のあるものであった。世界の年間炭素排出の5分の1は土地利 用変化によるもので、その大半は熱帯の森林減少を含んでいる。毎年1千3百万 ヘクタールの森林が失われ、森林減少は現在、化石燃料を大量に消費する全世 界の運輸業分野に由来するよりも多くの炭素を大気に加えている。世界にはもは や、地球温暖化における森林減少の役割を無視する余裕はない。

今後3ないし4年間は、国家政策の枠組と京都議定書後の気候保護制度の 両方において、森林減少と森林劣化に由来する排出削減(Reduced Emissions from Deforestation and Forest Degradation: REDD)を組みこむために相当多 くの議論が行われるであろう。REDD戦略を成功させるため、その計画と実施は 質の高い独立した研究に基づかねばならない。将来の気候保護制度への森林の 包合が効率的、効果的で、発展途上国の森林に依存する人々の利益を反映する ことを確実にするには、研究が必要不可欠である。

CIFORは森林減少の潜在的な原因に関する研究の実施において非常に多くの 蓄積を持ち、現在も熱帯における気候変動適応と緩和の両方に関係する多くの 研究を実施している。CIFORと共同研究者は、過去10年間にわたり森林減少の 原因と結果に関して50を越える出版物を生みだしてきた。 
本書は二つの目的をもつ。一つ目は、将来のREDD制度の設立に対する関連性 から、過去の森林減少研究を再検討し、研究知見を要約する。二つ目は、森林減 少と森林劣化を回避するための国家的および国際的過程を支持するために必要 な、今後の研究および方法論の開発に光をあてる。

本書の重要な教訓は、REDDは長く続いてきた森林への务威に対抗する機会 を提供する一方で、その成功には数多くの市場および統治における重大な欠陥 に立ち向からことが必要、ということである。現在の森林減少および森林劣化の 傾向の潜在的な原因を理解することは、将来確実に待ち受けている問題を克服 するための第一歩である。

フランシス・セイモア

CIFOR所長 


\section{謝辞}

本書は二つの段階を含む協同研究の努力の成果である。発展途上国におけ る森林減少に由来する排出の低減に関する問題、適切な科学技術と方法論に関 する問題点への注目、適切な情報と経験の交換」に焦点をあてるという気候変 動枠組条約第11回締約国会議一議題6 (FCCC/CP/2005/L.2)－の結論、に対 応して作成された国際林業研究センター(CIFOR)の報告書を活用したものであ る。この報告書はその後、2007年7月にシドニーで開催された気候と森林に関す る高級会合に対する貢献として、オーストラリア政府の支援によって更新された。 REDDへの影響に関する追加的な分析を含んでいる。

本報告は、私達が感謝の意を表したい数多くの人々の貢献と洞察から恩恵を 受けている。私達は、本書執筆の第一段階における貢献とリーダーシップに対し て特にClaudio Forner氏に感謝したい。私達はまた査読者、David Kaimowitz氏、 Pekka E. Kauppi氏、Rodel Lasco氏、Bernhard Schlamadinger氏の原稿に対す る論評、批判、提案を非常にありがたく感じている。

最後に、著者達は本書の準備に対する資金援助に対して、Charles Stewart Mott財団とDavid and Lucile Packard財団に感謝する。 


\section{要旨}

気候変動に焦点をあてた国際的および国家的な政策議論の場は、森林減少と 森林劣化を温暖化ガスの重要な排出源として認定した。土地利用変化からの炭 素排出は、現在の世界全体の炭素排出の5分の1を占案推定され、現存する 森林を維持することが、最も費用のかからない気候変動緩和策の選択肢として あげられてきた。その結果、発展途上国における「森林減少と森林劣化に由来す る排出削隇(Reduced Emissions from Deforestation and Forest Degradation: REDD)」が、2012年に終了する京都議定書の後継となる地球気候保護制度の一 要素として交渉されらるものとして、現われた。

本書の目的は、森林減少と森林劣化の直接执よび潜在的な原因として何がわ かっているのかと、その結果として起きる炭素排出を低減するために適用可能 な政策選択を、要約して示すことである。森林減少の社会的、経済的、環境的そ して政治的側面による複雑さゆえに、REDD政策の計画と実施は単純でも簡単な ものでもありえない、と本書の分析は示唆する。森林減少の潜在的な原因の多く は林業部門の外にあり、森林を保全するよりも別の土地利用の方がより利益をも たらす傾向がある。経济的な利益を求める行動を公益のために調整する制度は 一般に弱人、国家内にも国家間にも異なる利益をもつ人々がいる、という現実を REDD政策は取り扱う必要があるだろう。

REDDのために適切な政策枠組とは、森林に依存する地域共同体の福利を維 持することを確実にするとともに、森林減少の危険性が高く炭素蓄積量が多い場 
所を優先するのを助けるものである。十分に計画された枠組は、緊急に必要な人 的能力の開発を目的とし、その目的を達成するための障害となる制度的障壁を 克服する努力を含めなければならない。政策的枠組は、効率と有効性と公正性 の間に明白な折り合いを形成しうまく管理していかねばならない。

私達の分析は、地域に特有のさまざまな状況を取りあつかうよう政策が作られ る必要があることを示唆する。政策変更は、経済と、森林伐採の動機となる誤った 補助金の撤廃、持続的でない採取を許す森林産業政策の改革、地元の森林利用 者への資源利用と管理責任の権限委譲を含む規制と統治の改革、(炭素貯蔵に 加えて)森林による環境サービスに対する認識、を含める必要がある。これらの要 素の全てが、森林を基礎とする生計を守りながら、現存する炭素蓄積を保全する ための土台をつくるために、重要である。

本書は、森林減少に関する現時点での知見とデータの再検討から始まる。そし て、森林による炭素排出の測定と監視(モニタリング)、基準值(ベースライン)の 決定、に関する問題点および選択肢について要約する。森林減少の直接および 潜在的な原因に関する長期にわたる研究に基づく知見の概容を提供する。これ らの知見は、観察された傾向に関連づけられた統治の難問に光を当て、REDD政 策の選択肢を概説するための基礎として提示される。REDDを実施する新しい政 策に分析結果を関連づけた示唆が本書の結論となる。 


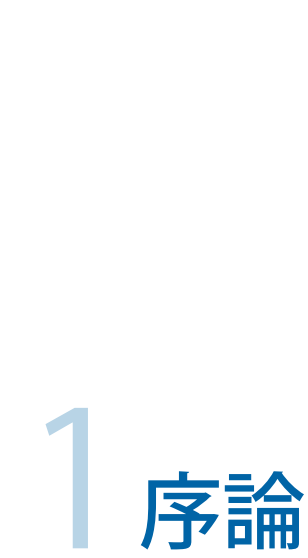

土地利用と土地利用変化及び林業分野 (Land use, land-use change and forestry: LULUCF)の活動は、炭素排出の主な供給源であり、地球温暖化に対 する活発な貢献者である。気候変動に関する政府間パネル (Intergovernmental Panel on Climate Change: IPCC)は、土地利用変化により毎年16億トンの炭素 が放出され、そのうちの主要な部分が熱帯の森林減少に由来すると、推定してい る(Denmanら、2007)。これは、現在の全世界の炭素排出の5分の1に相当し、化 石燃料集約的な全世界の運輸部門から生じているよりも多い。森林減少の回避 は、大量であるかもしれず、しかも正確な推定が難しいリーケージ(leakage、漏 洩)に関係した問題のために1、マラケシュ合意では適格なクリーン開発メカニズ ム(Clean Development Mechanism: CDM)活動として受け入れられなかった。 追加性とベースラインの設定も重大な障害と見なされた。最後に森林減少の回 避により発生する炭素クレジットの規模が非常に大きくなる可能性が、森林減 少の回避をCDMプロジェクトから除外するという決定に大きな役割を果たした (Auklandら、2003; Fornerら、2006; de Jongら、2007; Skutschら、2007)。

\footnotetext{
1 マラケシュ合意で規定された京都議定書の文脈については、文書FCCC/ CP/2001/13/Add.1、p.58(UNFCCC 2001)の中にある、draft decision/CMP.1 (土 地利用・土地利用変化と林業)付属第1項を参照のこと。
} 
気候変動の議論において森林減少を再検討すべきという多くの国々からの要 請に応えるため、2005年12月の気候変動枠組条約(United Nation Framework Convention on Climate Change: UNFCCC)第11回締約国会議(the Eleventh Session of the Conference of the Parties: COP 11)は、発展途上国における森 林減少に由来する排出削減のための政策を検討する2年間のプロセスを開始さ せた。このプロセスは、政策手法と積極的な動機付けを含む、適切な科学的、技 術的、方法論的な考察と経験の文書化および共有に焦点をあててきた。2012年 以降の国際的合意に向けた提案は、非附属書 I 諸国内の森林減少の回避を含 んでおり、公式で綿密な調査を実施中である。

森林減少は様々な原因でおこり、その大半は林業部門の外に端を発する。これ らの原因を理解することは、森林減少を抑制する適切な動機付けを特定し、また 同時に森林に生計を頼っている人々に益するために、必要不可欠である。森林は 社会に数多くの価值ある品物と公益を供給する。しかしなから、別の土地利用か ら得られる高い収益と森林生態系サービスに対する代償の欠如は、森林生態系 保護を不利な条件とし森林減少をもたらす動機を提供してしまう。

気候変動の緩和と適応のために新たに認識された役割によって、政策立案者 と一般大衆の注意が森林に再び集中し、森林減少と森林劣化の要因を理解す ることに新たな重要性をもたらした。英国政府により公表された気候変動の経済 学を分析したスターン報告書 (Stern、2006) は、将来の国際的気候枠組の4つの 「必須要素」の一つとして、さらなる森林減少の抑制を強調している。将来の気 候に関する合意に森林を含めるための議論には二重性がある:森林は現行の京 都合意の中に含まれない最大の排出源であること、排出削減の費用は他のほと んどの産業部門に比べ少ないことである。

REDDに出資するという京都議定書後の合意により、膨大な国際的資金の移 転がおきる可能性があることに、政策立案者や社会の注目が引きつけられてき た。REDD支払いにおいて起こりうる国際的価值の推定は、基礎となる仮定によ って変化する。二酸化炭素1トンあたり10ドルという控えめな炭素価格 $\left(\mathrm{CO}_{2 \mathrm{e}}\right)$ を 仮定すると、推定值は純現存価格1500億ドル (Chomitzら、2007) と毎年の収 益23－120億ドル(Ebeling、2006; El Lakanyら、2007)を含む。しかしょり積極 
的な仮定、炭素価格 ( $\$ 10-20 / \mathrm{tCO}_{2 \mathrm{e}}$ ) と森林減少の低減(20-50\%)では、毎年の REDD収益の推定值は70-230億ドルとなる（El Lakaryら、2007）。

そこで、そのように大きな資金が気候保護の重大性において森林保護への触 媒となるのか?という重要な疑問が生じる。つまるところ、木はお金で育つのか? 本書の目的はこの疑問に部分的な回答を与えることにある。

本書は、最新の森林減少速度のデータと知見の簡潔な概観、森林減少と森林 劣化に関する研究結果、そして適切な政策選択を、提供する。森林の変遷の異 なる段階にある発展途上国における森林減少と森林劣化に由来する排出の削減 (Reduced Emissions from Deforestationand Forest Degradation: REDD) に関する議論に対して特に関連深い問題に焦点をあてる。熱帯諸国からの事例 を引きながらも、気候変動枠組条約第13回締約国会議(UNFCCC COP13)の ホスト国であるインドネシアからの経験に、特別な注意を払う。そして本書は、 REDDを支持する経済的、調整的そして統治の改革に関する選択肢を提示する。 REDDを実施する新しい政策に分析結果を関連づけた示唆が、本書の結論とな る。 


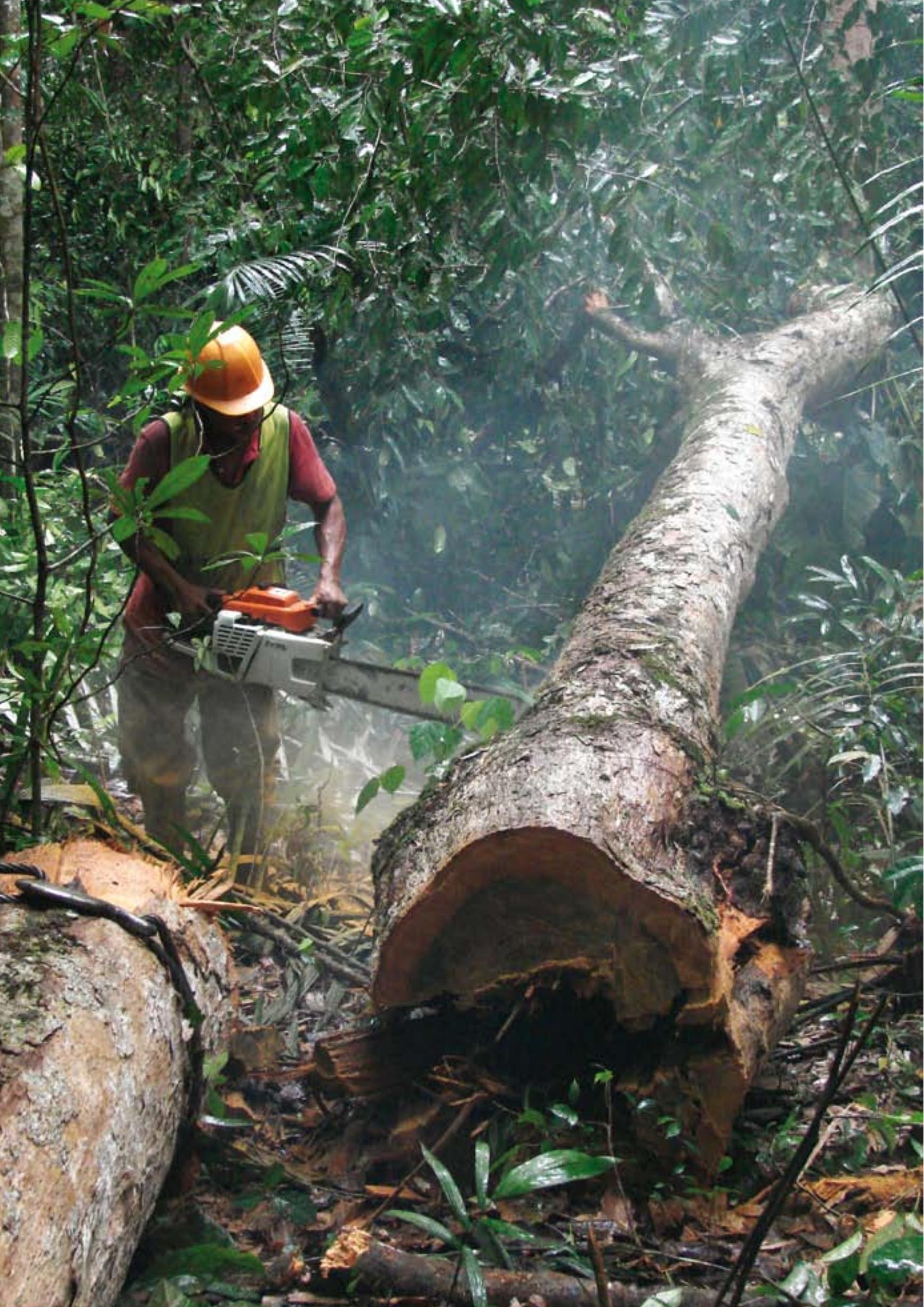




\section{森林減少についてわかって いること}

\section{1 最近の減少速度についての概観}

森林減少は地球環境変化の重大な要素のひとつである。熱帯林の減少速度は 速く、気候変動や生物多様性の衰失、洪水、沈泥 (siltation)、土袞の劣化に深刻 な影響を与えている。さらに、森林に依存する住民の生活や固有の文化、そして 未来の世代への木材や非木材林産物の供給が森林減少によって危険にさらされ る。

「森林減少」という用語はいろいろな意味に使われているので、明確な定義を しておくことが重要である。国連食糧農業機関(FAO) は二通りの異なる定義をし ている。一つ目は土地利用に基づき、森林減少とは森林から他の土地利用への 変換であると定義している。二つ目は林冠被覆で、森林減少とは林冠被覆が長 期にわたり10\%を割り込むことと定義している。地上で実際に森林減少を測る場 合、どちらの定義でも問題がある。前者には明確で一義的な森林 ${ }^{2} の$ 定義が必要 であり、後者は恣意的な閾値を用いている。

2 森林の定義: 樹高 $5 \mathrm{~m}$ を越す立木の林冠被覆が10\%を越す、または立木がそこでそ れらの閾値に達しうる、面積が0.5haを越す土地。ただし、農業または都市の土地利用 が優占する土地は含まれない(Penmanら、2003)。 
京都議定書も森林減少に独自の定義を持ち、それらは3条3項、同4項、12条に 適用されている3。ここでは土地利用の立場をとり、3つのパラメータ(樹高、林冠 被覆、最小面積)による森林の定義も併用している。締約国にはこれらのパラメー タを設定するある程度の自由がある(Penmanら、2003)。

森林減少の現状の推定值は方法により大きく異なる。空間分解能や標本数、時 間スケールが方法により異なるからである。森林減少速度を推定する際に、ある 方法をすべての地域と時期で一貫して用いれば、たとえその方法をどう選んだに せよ、このような問題はかなり軽減される。

世界で比較可能な森林減少の推定で最も広く用いられているのは世界森林資 源調査(Forest Resource Assessment: FRA)である(FAO、2006)。これによると、 現在の世界の森林面積は40億ha弱(陸地面積の約30\%)であり、地域により非常 に不均一に分布している(表1)。

表1: 世界の地域ごとの森林と森林被覆率（出典:FAO, FRA 2005)

\begin{tabular}{|c|c|c|}
\hline 地 域 & $\begin{array}{c}\text { 森林面積 } \\
\text { (1000 ha) }\end{array}$ & $\begin{array}{c}\text { 森林被覆凉 } \\
(\%) \\
(\%)\end{array}$ \\
\hline 東部および南部アフリカ & 226534 & 27.8 \\
\hline 北部アフリカ & 131048 & 8.6 \\
\hline 西部および中央アフリカ & 227829 & 44.1 \\
\hline アフリカ計 & 635412 & 21.4 \\
\hline 東アジア & 244862 & 21.3 \\
\hline 南部および東南アジア & 283127 & 33.4 \\
\hline 西部および中央アジア & 43588 & 4.0 \\
\hline アジア計 & 571577 & 18.5 \\
\hline ヨーロッパ言 & 1001394 & 44.3 \\
\hline カリブ & 5974 & 26.1 \\
\hline 中央アメリカ & 22411 & 43.9 \\
\hline 北アメリカ & 677464 & 32.7 \\
\hline 北部および中央アメリカ計 & 705849 & 32.9 \\
\hline オセアニア計 & 206254 & 24.3 \\
\hline 南アメリカ計 & 831540 & 47.7 \\
\hline 世界計 & 3952025 & 30.3 \\
\hline
\end{tabular}

3 マラケシュ合意で規定された京都議定書の文脈については、文書FCCC/ CP/2001/13/Add.1、p.58 (UNFCCC, 2001) の中にある、draft decision/CMP.1(土 地利用・土地利用変化と林業)付属第1項を参照のこと。 
また、FAOのFRAは森林減少が危険な速度で継続していることを示してい る。最新の推定值によれば、2000-2005年の間に毎年1300万haの森林が失 われ、純年間減少面積は毎年730万haである。しし注目すべきは、19902000年の間の平均純年間森林減少面積は890万haであり、これと比べると 2000－2005年には約17\%年間純減少面積が低下していることである。ただし 注意を要するのは、10年おきに実施されたこれまで3次の大規模なFRA(1980、 1990、2000年)で用いられた方法はそれぞれ異なり、特に国レベルで異なる期 間の比較を行うには非常に問題がある。

地域別で森林減少面積が最大なのは年間430万haの南アメリカで、400万 haのアフリカがそれに続く(表2)。2000-2005年の期間に、ブラジルだけで 310万ha強が主に牧草地への転換により失われ、アマゾン流域はいまだに熱帯 林減少の主なホットスポットである。データによれば、アフリカ・サヘル地域が砂 漠化のホットスポットであるとはいえない(Lepersら、2005)。

表2: 地域ごとの森林減少速度 (FAO，FRA、2005)

\begin{tabular}{|c|c|c|c|c|}
\hline \multirow{2}{*}{ 地域 } & \multicolumn{2}{|c|}{$1990-2000$} & \multicolumn{2}{|c|}{$2000-2005$} \\
\hline & 1000 ha & $\%$ & 1000 ha & $\%$ \\
\hline 東部および南部アフリカ & -1731 & -0.71 & -1702 & -0.74 \\
\hline 北部アフリカ & -1013 & -0.72 & -982 & -0.73 \\
\hline 西部および中央アフリカ & -1631 & -0.56 & -1356 & -0.48 \\
\hline アフリカ計 & -4375 & -0.64 & -4040 & -0.62 \\
\hline 東アジア & 1751 & 0.81 & 3840 & 1.65 \\
\hline 南部および東南アジア & -2578 & -0.83 & -2851 & -0.98 \\
\hline 西部および中央アジア & 34 & 0.08 & 14 & 0.03 \\
\hline アジア計 & -792 & -0.14 & 1003 & 0.18 \\
\hline ヨーロッパ言 & 877 & 0.09 & 661 & 0.07 \\
\hline カリブ & 36 & 0.65 & 54 & 0.92 \\
\hline 中央アメリカ & -380 & -1.47 & -285 & -1.23 \\
\hline 北アメリカ & 17 & n.s. & -101 & -0.01 \\
\hline 北部および中央アメリカ計 & -328 & -0.05 & -333 & -0.05 \\
\hline オセアニア計 & -448 & -0.21 & -356 & -0.17 \\
\hline 南アメリカ計 & -3802 & -0.44 & -4251 & -0.50 \\
\hline 世界計 & -8868 & -0.22 & -7317 & -0.18 \\
\hline
\end{tabular}

注:パーセントは各期間中に消失または増加した森林の残存する森林に対する年平均比 率である。 
年間森林減少率(ある地域における現存森林面積に対する森林減少面積の比 率)の点では、中央アメリカと東南アジアが最も高い。アジアには急速な土地被覆 変化、特に乾燥地の劣化が、現在世界で最も集中している。南アジアおよび東南 アジアの平均年間森林減少率は約 $1 \%$ ありり、インドネシアでの $2000-2005$ 年 の平均純年間森林減少率は $2 \%$ に達している。その一方で、アジアのいくつかの 国ではかなりの規模の再植林も行われている。インドとバングラデシュは森林率 を安定化させた。また、中国は年間410万ha(年間2.2\%)という驚くべき森林増加 面積をもち、これは1990年代の年間増加面積の2倍に相当する。

FAOのFRAのほかにも、熱帯林減少率を推定した研究はある。たとえば、 Tropical Ecosystem Environment Observation by Satellite (TREES)プロジェク トでは、高分解能のサンプルデータを用いて湿潤熱帯林の森林消失を推定した。 FAOのFRAと比べると、ラテンアメリカとアジアの2大陸では1990年代の総森林 減少面積はだいたい一致している。ラテンアメリカでは年間440万ha、アジアで は年間280万haの総森林減少である。しかし、アフリカの乾燥林とサバンナでは 特に著しく異なっている(Chomitzら、2007: 表3)。

\section{表3: 1990-97年の間の推定年間森林減少面積 (百万ha) (出典: Archardら、2002; Chomitzら、2007)}

\begin{tabular}{|c|c|c|c|c|c|c|}
\hline & \multicolumn{4}{|c|}{ 湿潤林 } & \multicolumn{2}{|c|}{ 乾燥林 } \\
\hline & $\begin{array}{l}\text { 中南米およ } \\
\text { びカリブ(ブ } \\
\text { ラジルを除 } \\
\text { く) }\end{array}$ & $\begin{array}{l}\text { ブラジル、ア } \\
\text { マゾン }\end{array}$ & アフリカ & アジア & $\begin{array}{l}\text { 中南米およ } \\
\text { びカリブ }\end{array}$ & アフリカ \\
\hline 森林減少 & $1.08 \pm 0.55$ & $1.43 \pm 0.88$ & $0.85 \pm 0.30$ & $2.84 \pm 0.90$ & $1.9 \pm 1.1$ & $1.5 \pm 0.6$ \\
\hline 森林劣化 & $0.61 \pm 0.46$ & $0.22 \pm 0.21$ & $0.39 \pm 0.19$ & $1.07 \pm 0.44$ & n.s. & n.s \\
\hline 再成長 & $0.20 \pm 0.11$ & $0.08 \pm 0.11$ & $0.14 \pm 0.11$ & $0.53 \pm 0.25$ & n.s. & n.s \\
\hline
\end{tabular}

年間森林減少面積が報告により異なる理由は、それぞれに用いる定義と方法 が異なるからである。例えば、ランドサット画像に基づく1990年代後半のインド ネシアの森林減少面積は年間170万haであった(Holmes、2000)。一方、国別報 告に基づきFAOがまとめた推定では年間190万haであった(Stibigら、2007 中 FAO 2007)。 
Mathews（2001)とLepersら(2005)はそれぞれ、最近何十年かに出された森 林被覆と森林減少のさまざまな評価で用いられた定義と方法を解析した。両者と も現在の森林被覆についての把握が不十分であることを指摘し、森林被覆およ び森林被覆変化のベースライン情報を集めるためには標準化され世界的に承認 された定義と方法が緊急に必要であると主張している。理想的には、広く認めら れた総合的なモニタリングシステムによって、森林被覆データや指標值が 10 年 に1度よりもずっと頻繁に作成され、急速に発展しているREDDのためにタイムリ 一な情報を繰り返し提供できることが望ましい。このような努力は、2012年以降 の気候問題やREDD活動に必要なデータと分析を提供することにより、世界のさ まざまな参加者によるパートナーシップを通じて受け入れられるであろう。

衛星データを解析して森林被覆の変化を計測する適当な方法はすでに多くあ る。肉眼写真判読から複雑なデジタル解析まで、全面図化からホットスポットの 解析、そして統計的標本抽出まで、その方法はいろいろである。適用できる方法 は、国の能力や森林減少のパターン、森林の特徴によって変わってくる。未来に は新しい複雑な方法が使えるかもしれないが、当面の大きな問題は、国別べース ラインを設定するためにどのように過去の森林減少を正確に求めるかということ である(2.3参照)。

国別REDD制度を実行する上でもうひとつの問題は、森林被覆の変化を効果 的に捉えるために必要な高分解能データの、価格と入手の手段である。国レベ ルで実用化された森林減少モニタリングシステムを持っている発展途上国は少 ない。ブラジルとインドは数少ない例である。ただし、彼らのシステムはまだ高 分解能データを用いていない。インドとブラジルはリモートセンシング衛星画像 (LandsatまたはTerra画像)の受信局や彼ら自身の衛星(それぞれIRSと CBERS)を持っている。そのほかの国、例えばペルーやボリビア、インドネシア でも、リモートセンシング情報を用いて森林の評価を行っている(DeFriesら、 2007)。

森林劣化は森林減少ではない。森林劣化の定義には、林冠率や生態的機能、 炭素蓄積量、その他の森林の属性に関連してさまざまなものがある(Penmanら、 2003)。REDDの観点からは、森林劣化とは、伐採または他の原因でのバイオマ ス除去による部分的なバイオマスの喪失、と定義できる。たとえ単位面積当たり 
の炭素放出は森林減少による森林の完全な除去と比べて小さなものであり、ま た時には植生の回復が早く喪失は一時的なものであったとしても、森林劣化は広 い面積で起きており、森林の䍌失による炭素排出全体の中で大きな部分を占め るであろう(Asnerら、2005)。森林劣化の監視は森林減少よりも技術的に難しく、 リモートセンシングで森林劣化を見つけるためには高分解能データが必要である (DeFriesら, 2007)。

\section{2 森林推移}

「森林推移」とは、経済的発展によって森林が一度消失してから回復する長 期にわたる過程のことである(Mather、1992; Rudelら、2005; Kauppiら、2006; Mather、2007)。図1に示したとおり、開発初期段階の森林減少は農産物の需要 や関連する社会基盤の整備により加速される。ある段階で開墾は最大に達しそそ の後は減少する。このような現象は一般的に2つの主な要因により説明される。 まず、歴史的に欧州や北アメリカなどの先進地域ではより高収入の仕事を求めて 人々は農業を捨てた。そして、放棄された農地にはしばしば森林が回復した。二 つ目は、より裕福な人々が希少な林産物(特にアジアで)あるいは森林サービス (特に欧州や北アメリカで)を求めて森林の回復を後押しした。この場合、森林被 覆は天然更新および植栽により増加した。

\section{3 将来のREDD制度に対する示唆}

森林減少からの排出を削減させる政策を実行するためには、再現性があり一 貫した結果が得られ図化精度の標準を満たしかつ国レベルに適用可能な、森林 減少計測·監視システムが必要である。図1のコスタリカの例(Kleinnら、2002)が 示すように、定義の違いと森林被覆推定の不確かさのために、REDD制度のベー スライン設定には大きな困難が予想される。

リモートセンシングは、地上観測を併用することにより、計測と監視の要とな る。そのような技術を莫大な面積の森林とそのバイオマス中に炭素を保持してい る国々でも使えるようにするには、費用効果的でもなければならない。DeFriesら （2007）は国レベルでの森林減少・森林劣化による排出の推定にかかるさまざ まな問題点を整理した。 
a)

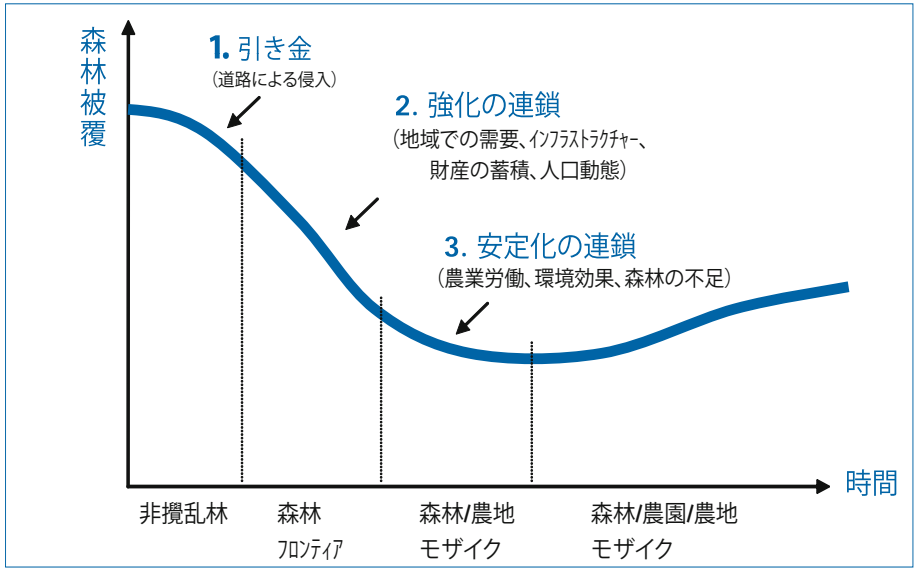

b)

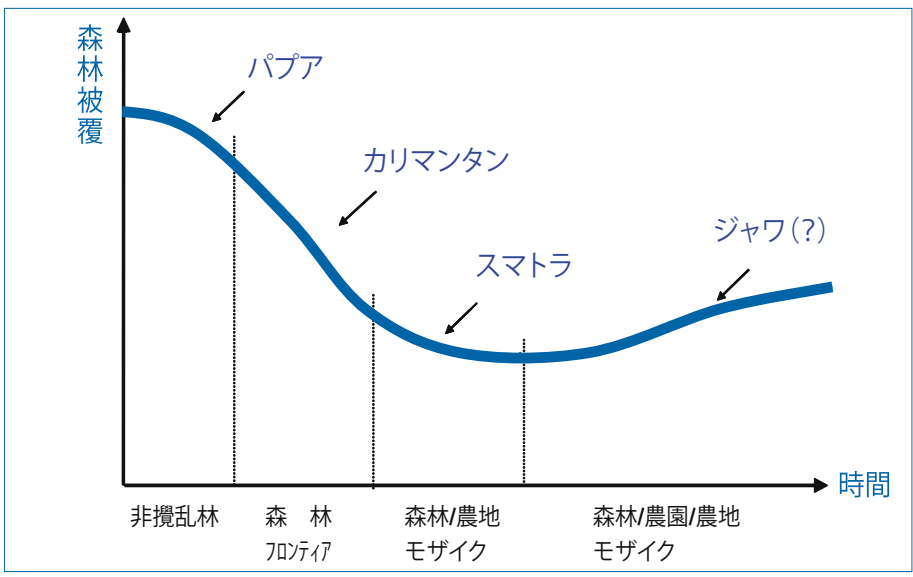

c)

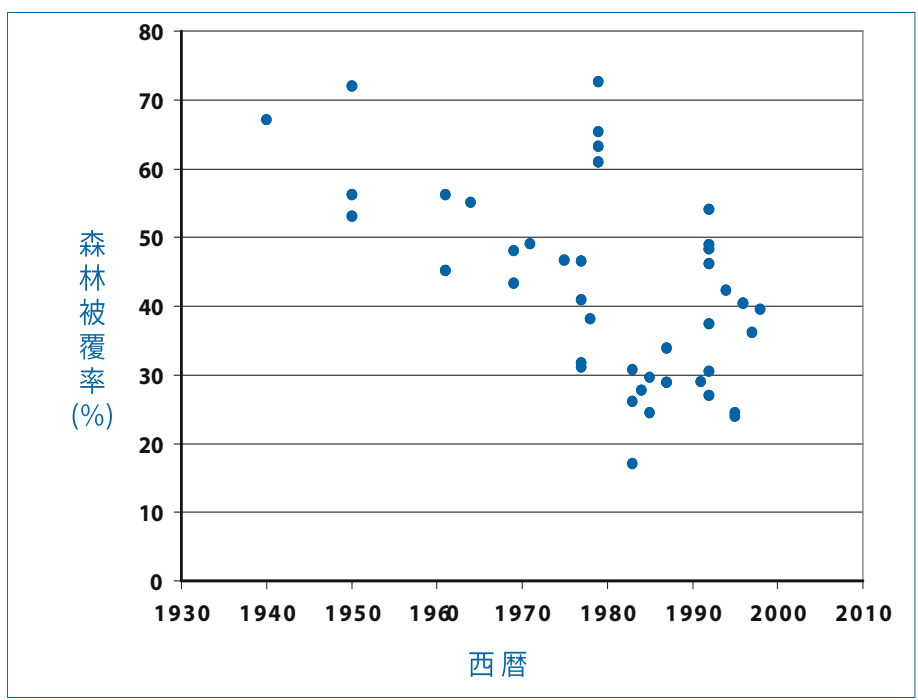

\section{図1: 森林推移}

a）農産物への需要と経済発展による農業地代と林業地代の動態を示唆する (出典: Angelsen、2007)

b）インドネシア各州の森林推移の概略的な段階

c） 1940-1998年の間のコスタリカの森林率の変遷。各点は公表された值を示す (出典: Kleinnら、2002) 
・ 過去の面積の推定值・計測值を確定するためのガイドラインとプロトコル を決め、ベースラインとベース期間を合意の上で決める必要がある(例え ば、“経常の事業(business as usual)”や森林減少傾向予測などのシナリオ をモデルにより内挿する)。森林減少の傾向は年々の変動が大きいので、化 石燃料による排出を取り扱うのとは異なり、ある 1 年のデータを外挿して森 林からの温暖化ガス排出を求めるのでは不正確である。べース期間はむし ろ最低でも最近の5ないし10年とするべきである。過去の面積および排出 量の軌跡を求める期間は、森林減少速度の大きな年々の変動を考慮して、 単年度ではなく複数年度の森林減少実績に基づくべきである。

- 多くの発展途上国では、森林減少が進行する森林の炭素蓄積量とその後 の炭素動態は明らかでない。ただし、基本データと炭素算定のガイドライ ンはIPCC Good Practice Guidanceレポート(Penmanら、2003)とIPCC Greenhouse Gas Inventory Guidelines(IPCC、2006)という形ですでにあ る。しかし、炭素蓄積量の変化をモニタリングするために、衛星と航空機画 像を組み合わせた新しい技術と方法が求められている。これらにより、森林 減少による温暖化ガス排出量の変化を算定する際の不確実さを減少でき るものと考えられる。これらの技術をさらに試験し実用化するために、国際 的な協調が必要である。

REDDの枠組みが効果的となるためには、森林減少による排出量推定值を比 較可能かつ一貫性のある值として求められるモニタリングの方法論と報告システ ムが必要である。包括的なモニタリングの枠組みには技術、管理、制度の要素が ある(Penmanら、2003)。管理過程には、計画、報告方法、品質保証・品質管理、 さらに組織と人員配置の部分がある。制度の要素とは、国際、国、地方のレベルに おいて炭素関連活動を支援するために必要な、制度上の整備のことである。コス タリカとメキシコでのモニタリングおよび報告システムの事例研究によれば、プロ グラムを成功させるためには能力強化が必要である(Karousakis、2007)。

信頼できる炭素からの収益をREDDプログラムで発生させるためには、対象地 域が森林減少の危機にさらされていることをべースラインで示さなければならな い。Brownら (2006)はREDDのベースラインを設定するため3段階の方法を提案 している。(1)過去の土地利用変化と森林減少の推定。過去にベースラインを変 
化させた要因解析とそれらの重要度の順位付けを含む。これらの要因は「期間1 (調整期間)」での重要さに準じて重み付けされる。(2)森林減少のベースライン 予測。将来の土地利用变化予測抢よび予測される森林減少速度と炭素蓄積予測。 (3)合意された間隔(例えば10年)ごとのベースラインの見直しと再評価。

国レベルでの森林減少削減による温室効果ガス排出削減量の推定とベース ラインの設定に関し、科学者やREDD枠組みを実際に使いたい人々は多くの方 法論的問題に直面している。しかし、既存のIPCCによる方法(Penmanら、2003; IPCC 2006)は、大きいスケールで実行しても十分に安定していて技術的にも妥 当な、国レベルのREDD戦略を決めるのに適切な基礎を提供する。

（訳 鷹尾 元） 


\section{森林減少と森林劣化の直 接的および潜在的な原因}

効果的なREDD体制の設計には森林減少と森林劣化の原因に関する明快な理 解が必要である。幸運なことに、それらの原因を明らかにする一連の重要な研究 が存在する。以下に続く節では重要な研究結果を要約する。

\section{1 定義と区別}

\section{森林減少と森林劣化:}

前章で説明したように、森林減少は $10 \%$ を下回る林冠被覆の低下として定義 することができる。そのため、閾值を超えて森林減少となる前に著しい森林劣化 が起こりうる。択伐は通常、その閾值まで林冠被覆を減少させず、森林減少とい うよりむしろ森林劣化を引き起こす。森林減少は通常、より劇的な土地利用の転 換、しばしば樹木の皆伐と他の土地利用への転換、主として農業、に特徵づけら れる。しかしながら、後述するように森林劣化はしばしば多様な道筋(例: 伐採施 業が農民に容易な交通路を提供すること)で間接的に森林減少を導くことがあ る。露天掘り、都市の拡大、もしくはその他の利用のための、土地開拓もまた森林 減少を引き起こすことがある。

直接的な原因と潜在的な原因：

森林減少と森林劣化の原因は二つの範疇に効果的に分類される。一目は、 開拓もしくは森林を減少させる活動に直接関連し、直接的もしくは直近の原因 
と呼ぶことができる。二目のカテゴリーは、これらの直接的原因を推進する 背景にある社会的要素を含み、潜在的原因と呼ぶことができる (Kaimowitzと Angelsen、1998)。加えて、KaimowitzとAngelsen(1998)は森林減少につなが る活動や行為主体(例えば、小規模農家による農業の拡大)を指す「森林減少の 根源」という言葉を紹介した。

\section{(森林産業)部門内と部門外の要因：}

また別の区別は、森林(産業)部門そのもの内に源を発する原因(いわゆる部 門内要因)による森林減少および森林劣化と、他の(産業)部門に源を発する原 因(部門外要因)によって起きる行為である(Contreras-Hermosilla、2000)。実 際、ほとんどの原因は林業部門そのもの内で作用せず、主として（食料、繊維もし くは燃料のための)農業との関係、もしくはインフラストラクチャー開発、産業的 な繊維需要、その他、に由来している。森林部門外の活動は通常、木材の伐出よ りも森林減少により大きく寄与する。

森林減少と森林劣化は普通、要因の組み合わせにより起きる。森林減少の異な る原因(直接的および潜在的、部門内的および部門外的)が複雑かつ様々な方法 で相互に作用する。例えばSunderlinとWunder(2000)は、異なった市場と制度 のもとで石油景気がどのように相反するやり方で森林減少に影響を与えるかを 明らかにしている。石油からの富が農業の競争力を低下させ森林保護につなが ることがある。その一方、それが主として道路建設、フロンティア(開拓地と未開拓 地の境界地帯)の拡大、および流通補助などに使われると、同じ富が逆の効果を もつ。このように、様々なマクロ経済的政策の結果により、森林の状況はさまざま に変化する。Box1は直接的および潜在的原因が部門内および部門外要因によっ てどのように推進されるのか、また別の実例を提供する。

152力国における森林減少様式の分析から、GeistとLambin(2002)は森林減 少に関する3つの支配的な根源(農業の拡大、樹木の採取、インフラストラクチャ 一の拡大)を示唆している。これらは5つの主要な潜在的原因、すなわち人口動 態、経済、技術的側面、制度、文化の多様性、と相互に作用する。以下に示すよう に、彼らの研究は、直接的および潜在的原因の組み合わせによって、森林減少は 最も良く説明できると結論する。 


\section{Box1: 産業部門内外の要素の複雑さ}

食肉と紙と建築資材に対する需要を増大させる都市での収入の増加を、 一例として考える。これらの消費者需要は、牧場およびパルプと木材への需 要を増加させる。これら三つの全てが、森林減少と劣化への圧力を強くする。 都市での収入の急増は「潜在的原因」の役目を務める。しかしそれは、一つの 「産業部門外」直接原因(畜牛牧場の拡張)と、二つの「産業部門内」直接原 因(建築用材とパルプ材のための森林収穫)の引き金となる。この複雑さに加 え、都市でのより高い収入は、田舎の森林地帯から都市へと労働者を引きだ すことがある。この産業部門外要因は、森林への圧力を軽減しそして森林の 再生を促進することにより、前の三つの影響を弱めたり、さらには凌駕したり するかもしれない。

\section{2 森林減少と森林劣化の直接的原因}

以下は、(上述した3つの主な根源に関連して) 文献で記述されてきた森林減少 と森林劣化に関する主要な直接的原因である：

\section{農業の拡大：}

農業活動は、恒久的農地の設立、移動耕作、および牧草地を含み、森林の開拓 と転換を引き起こす。農業フロンティア(開拓地と未開拓地の境界地帯)の拡大 は通常、森林減少の明らかに最も主要な誘因である。移動耕作は、森林の再成長 と二次遷移がこの方式の農業利用に続いて起きるーただし、長期休閑が維持さ れうる極めて低い農村人口密度下に限られる一ため、他の農業活動よりも有害 ではない(GuariguataとOstertag、2001)。林地転換の決定を刺激する直接的原 因は以下を含む：

- 好適な環境条件 (例: 排水と土袞養分の良い地域の森林は、より農地に転 換されやすい)

・農業生産物の高価格(より高利益な生産、そのためのさらなる開拓)

・ 低賃金(森林開拓のより低い費用、そのためのさらなる森林減少)

- 人口動態の変化(例：人口増加と高い農村人口はさらなる森林減少を進め ることがある) 
KaimowitzとAngelsen(1998)は、中部アメリカの食肉生産とブラジルの大 豆生産という中南米の事例から、農業の拡大が森林減少の主要な原因であ ると結論している。インドネシアでは、森林のアブラヤシ農園への転換が重要 な誘因である。未加工ヤシ油の価格上昇はアブラヤシが植えられる土地の拡 大を推し進めている。これらの事例のそれぞれで、小規模農家によるよりも大 規模な産業的農園によって、森林減少がより大きく推し進められている。土地 開拓によって生まれる木材からの追加的な利権が、荒廃地よりもむしろ森林 における農園の拡大を推し進めている。この10年で、インドネシアでアブラヤ シが植栽された土地はほぼ3倍になり、2005年には合計560万haとなった （BisInfocus、2006）。Box2は、東南アジアの泥炭地帯の劣化と森林減少に様 々な要素がどのように作用してきたかを説明する。

\section{Box2: 東南アジアの泥炭地帯で森林減少を引きおこした要因}

この10年間にわたり、アクセスのそしい泥炭および湿地の森林一地下 有機物の形態で非常に大量の炭素を蓄積した脆弱な生態系一に合法 および違法な伐採が拡大してきた。急激に伸びる中国でのパルプ需要 （Wright、2004）とヨーロッパでの粗ヤシ油の需要（Reinhardtら、2007） を、満たすための大規模なパルプ材植林地とアブラヤシ農園の造成が、 泥炭地帯での急速な森林減少と森林劣化を引きおこしてきた。その結 果、東南アジアの2700万ヘクタールの泥炭地帯において、1200万ヘクタ ールの森林がこの10年間で失われたり劣化したりしてきた(Hooijerら、 2006)。直接的原因はおもに、開拓のための火入れとプランテーション開 発のための排水であった。

\section{樹木の採取：}

樹木の採取は森林劣化の主要な部門内要因で、直接的もしくは間接的に森 林減少を引き起こすことがある。樹木は、木材、パルプ用材、燃料材、および木 炭のために森林から採取される。伐採施業は一般的に森林を劣化させるが、 択伐は必ずしも深刻な森林劣化もしくは森林減少を誘発しない。低インパク ト伐採(Reduced Impact Logging: RIL)に関する多くの研究が、造林および 
収穫技術、そして収穫前および収穫後の施業技術を開発してきた。RILおよび 「RILを超えた」提言の実行により、伐採後の林分、関連する生物多様性、そし て生態系サービスへの被害を最小限にするとともに、伐採が森林の転換を導 く機会をも低減できる(Meijaardら、2005; Gustafsonら、2007)。

しかしながら、統制のとれていないあるいは規制の少ない樹木採取は、合 法であっても違法であっても、しばしば森林劣化を招きそして間接的に森林減 少を誘発する。また所有権が不明瞭だったり執行がずさんな場所では、伐採に 関係する道路建設は入植と森林の農地への転換を容易にし、頻繁に森林減少 を招く(Kaimowitzら、1998)。Box3は伐採路が森林減少を助長する条件を記 述する。

\section{Box3: 伐採と森林減少}

伐採と森林減少は道路建設を通じてつながっている。次の条件が同時 に起きるとき、移住や土地開拓を促進することで、伐採は森林減少を促進 する(Kaimowitzら、1998)。

・ 道路建設が森林地帯への新しい交通路を開く。

・森林所有権や採集活動に対する規制が不十分にしか施業されない。

・森林地域が農地転換のための発展可能性をもつ。

・出身地域での人口および貧困に関係する要因により、大量の移住者 流入がある。

ずさんな伐採施業一大量の可燃性廃棄物をあとに残す一は、商用もしくは 自給のための土地開拓に使われる火の延焼に対して、森林を脆弱にし、森林 をさらに劣化させる(Nepstadら、1999; Meijaardら、2005; Iskandarら、2006; Gustafsonら、2007)。森林地帯がいったん劣化すれば、ほとんどの場合放棄 され「誰でも利用可能な」状態で放置される(後述)。劣化した森林は、他の土 地利用への転換可能とされることがある。インドネシアには、健全な森林が非 正規に「劣化した」とされて、無節操な投資家が農園開発の許可を得、木材収 穫を実行した後に農園開発をせず土地を放棄することにより、「棚ぼた」の利 益を上げてきたという証拠がある(Barr、1998; SmithとScherr、2003)。 
伐採およびパルプ用材の皆伐は東南アジアにおける森林減少の主要な原 因で、その一方サハラ以南アフリカの乾燥林では非持続的な燃料材採取と木 炭生産が基本的な原因である(KaimowitzとAngelsen、1998)。インドネシア など東南アジアでは、違法伐採が森林劣化の主要な加速要因として現れてき た(Tacconi、2007)。鉱業など他の「部門外」産業活動も、直接の利用と人口 増加を通じて、相当量の木材もしくは木炭を使用し、その結果高いレベルでの 森林劣化を引き起こす。

\section{インフラストラクチャーの拡大：}

最後に、森林は、道路、居住地、公共サービス、パイプライン、露天掘り、水力 発電ダム、その他のインフラストラクチャーの建設、によっても開拓されること がある。これらの原因の全てが森林地域の大規模開拓の大きな要因となるわ けではない。しかし間接的には、道路の建設と改善はインフラストラクチャー 開発のうちで最も大きく森林減少に寄与する(Chomitzら、2007)。これは、道 路が直接占有する空間ではなく、流通費用の低下によって、遠隔地における生 産活動が可能となるためである。このような活動は、木材収穫、木炭の採集、そ して続いて起こる農地および牧草地への転換としておきるサイクルと同様に、 しばしばフロンティアの拡大と森林破壊を推進する(Wunder、2000)。

森林減少の直接的な原因は国ごとに大きく異なり、表 4 でGeistとLambin （2002)が描写するように、農業とインフラストラクチャーの拡大、商業的およ び家内的木材産物の需要、に大別される(表4)。 


\begin{tabular}{|c|c|c|c|c|c|c|c|c|}
\hline & \multicolumn{2}{|c|}{$\begin{array}{l}\text { 全事例 } \\
(\mathrm{n}=152)\end{array}$} & \multicolumn{2}{|c|}{$\begin{array}{l}\text { アジア } \\
(n=55)\end{array}$} & \multicolumn{2}{|c|}{$\begin{array}{l}\text { アフリカ } \\
(\mathrm{n}=19)\end{array}$} & \multicolumn{2}{|c|}{$\begin{array}{c}\text { ラテンアメリカ } \\
\quad(\mathrm{n}=\mathbf{7 8})\end{array}$} \\
\hline & 観測数 & (\%) & 観測数 & (\%) & 観測数 & (\%) & 観測数 & (\%) \\
\hline 農業の拡大 & 146 & 96 & 55 & 100 & 16 & 84 & 75 & 96 \\
\hline 恒久的農地 & 73 & 48 & 24 & 44 & 10 & 53 & 39 & 50 \\
\hline 生計のための農業 & 61 & 40 & 20 & 36 & 10 & 53 & 31 & 40 \\
\hline 放牧 & 70 & 46 & 3 & 6 & 3 & 16 & 64 & 82 \\
\hline 移動耕作 & 63 & 41 & 24 & 44 & 8 & 42 & 31 & 40 \\
\hline 焼畑農業 & 46 & 30 & 24 & 44 & 7 & 37 & 15 & 19 \\
\hline 入植 ${ }^{a}$ & 61 & 40 & 23 & 42 & 4 & 21 & 34 & 44 \\
\hline 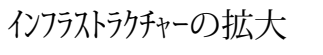 & 110 & 72 & 36 & 66 & 9 & 47 & 65 & 83 \\
\hline 流通路の拡大 & 97 & 64 & 26 & 47 & 9 & 47 & 62 & 80 \\
\hline 道路 & 93 & 61 & 25 & 46 & 9 & 47 & 59 & 76 \\
\hline 居住地・市場の拡大 & 41 & 27 & 12 & 22 & 3 & 16 & 26 & 33 \\
\hline 木材の採取 & 102 & 67 & 49 & 89 & 13 & 68 & 40 & 51 \\
\hline 商業(輸出用) & 79 & 52 & 43 & 78 & 5 & 26 & 31 & 40 \\
\hline 薪炭材 (家内用) & 45 & 28 & 18 & 33 & 10 & 53 & 14 & 18 \\
\hline その他の要因 & 52 & 34 & 17 & 31 & 10 & 53 & 25 & 32 \\
\hline
\end{tabular}

注: 観測数は複数要因を含む。\%はそれぞれの事例の全事例に対する相対的割合を百分率で示す。 相対的割合は数值を丸めているため、合計が100\%にならないことがある。

a 移住と再移住を含む。

b 土地条件および社会、もしくは生物物理学的に引き起こされる事柄といった誘発的な環境要因。 (出典:GeisitとLambin、2002)

\section{3 森林減少と森林劣化の潜在的原因}

過去10年にわたり、森林減少と森林劣化に対する、マクロ経済、脆弱な統治、 他の社会的特徵、の強い影響力が詳細に報告されてきた(例えば、Chomitzら、 2007を参照)。森林減少の主要な潜在的原因は以下で説明される。 


\section{マクロ経済的要因:}

市場の力に敏感な者ならたいてい土地を開拓して、転換された林地で栽培さ れる(もしくは放牧される)生産物へのより高い需要を満たそうとするだろう。農 業商品生産のために森林が開拓される場合、経済発展の初期段階においては森 林減少を増加させることがある。経済発展の後期段階では、農業生産が集約的に なり、経済にしめるサービス業の割合が増加し、森林生産物とサービスに対する 需要の高まりが立木地をより価值があるものとするにつれて、森林への圧力は減 少する。Box4は、森林減少と森林劣化のマク口経済要因の一覧を示す。

\section{Box4: 森林減少と劣化を促進するマクロ経済的要因}

・通貨の下落は、農地拡大をより利益のあるものとしうる。

・緊縮調整政策は都市の経済を縮小し、人々を農業フロンティアに押しも どしうる。

・ 粗放な土地利用産業と木材産業を輸入品から守るような貿易政策は、地 元での需要を満たすための森林への圧力を増すことがある。

・燃料および運送に対する補助は、僻地での木材採集を進める、もしくは 土地開発をより利益性の高いものとすることがある。

(KaimowitzとAngelsen(1988)、Wunder(2003)を参照のこと)

先に議論したように、農業のより高い収益性(農業地代)は、森林を他の利用へ と転換する基礎的で主要な経済的要因である(WunderとVerbist、2003)。農業 生産物の価格上昇と投資費用の低下は農業の収益性を向上させ、生産に使われ る土地の拡大を招く。森林減少に重大な影響を与える可能性がある他のマク口 経済的要因には、対外債務、外国為替政策、森林減少(主に農業および牧畜)と 森林劣化(主に木材伐出)に関連する産業部門の貿易政策などが含まれる。しか し、森林に関わるこのような政策の正味の影響は、非常に変わりやすい。例えば、 通貨の切り下げもしくは通貨の下落は輸出を刺激する。そして森林減少への影 響は、輸出作物が開拓された森林での耕作に適しているかどうかに依存する。 
経済危機もまた、森林減少を刺激する。1997年にインドネシア経済が崩壊した とき、正規の産業部門(フォーマルセクター)で職を失った多くの人々が、副次的 な収入を得るために森林に入った。彼らの活動には、開墾、伐採活動を休止して いる生産林における違法伐採、そして魚と爬虫類の採集を容易にするための火 入れ、が含まれる(Chokkalingamら、2006)。しかし経済危機はまた、そうでなけ れば森林減少速度に著しい影響をもったはずの大規模インフラストラクチャーお よび土地開発プロジェクトを停止させた。

林産業の拡大を支援する政策と関連する債務は、森林減少を推し進める大き な力となる。生産容量がいったん整えば、植林地からの原木供給が足りないとき には、市場および政策の要因はともに天然林から原木の供給を維持するよう圧 力をかける。例えばインドネシアでは近年、パルプ産業は約 $70 \%$ の瀻維を天然 林から得ている(Spek、2006)。Box5は、この供給と需要の構造的不均衡を取り 扱う債務政策の機会喪失を説明する。

\section{統治要因：}

統治は森林に何が起こるかを決定する主要な役割を果たす。森林減少と森林 劣化は森林所有権と制度の複合効果に起因する。これらが乱獲につながる一連 の動機付けを相乗的に行うのである(Ostrom、1990)。

森林所有権に関しては、森林減少(森林を開拓したこと)によって土地所有権 が得られるような制度を含め、ずさんに定義された所有権の結果として森林減少 と森林劣化が起こりうる。所有権が不明瞭、重複したり貧弱な場所では、天然資 源からの長期にわたる収入に対する投資の動機もまた乏しい。例えば、公有林と された土地がほとんど規制されなかったり「警備」されない場合には、これらの土 地は「誰でも利用可能」資源として取り扱われ略奪的利用にさらされる(Agrawal とOstrom、2001)。所有権が書面でも実際にも保証されているとき、持続的管理 に対する長期的な投資が可能となる。

確実な所有権は不可欠だが、しかしそれだけでは持続可能な森林管理を確実 にするにはしばしば不十分である。所有権が共同で保有されていても、森林管理 に対する明確な権利と責任を明示する地方制度がなければ、森林劣化が起きる ことがある(Ostrom、1990; 1999)。 


\section{Box5: 森林減少と森林劣化の潜在的原因としての法人債務政策}

1997年と1998年にインドネシアのルピアが暴落したとき、輸出を基礎と する木材加工企業は、国内及び国際金融機関、特に銀行に対する利息支払 いができなかった。同国の主要な森林複合企業を含め、大半の企業は法人 債務を履行せず、実質的に破産させられた。経済危機の結果による金融機 構と実業部門の崩壊を防ぐため、国際通貨基金(International Monetary Fund: IMF)と世界銀行の支援を受けたインドネシア政府は、同国の病ん だ金融部門の資本再構成を監督するインドネシア金融再編庁 (Indonesian Bank Restructuring Agency: IBRA)を設立した。この立場において、 IBRAは、ほとんど全ての木材関連企業と森林複合企業に所有された全ての 銀行に対する管理権を手に入れた。

IBRAは、その管理下にある破産者の財産から最も多くの金融利益を回収 するための法的権限をもつ、強力な政府機関であった。国際援助集団からの 支援に応え、IBRAの債務再編成過程と債務帳消しを森林産業の加工能力低 減に連動させることをインドネシア政府は公約した。その政策が実施され、イ ンドネシアの多くの紙パルプ企業とその他の森林複合企業は持続的な木材 供給により支持されるレベルまで加工容量を低減させることを強いられた。 インドネシアが経済危機に突入したとき、木材産業による年間需要量は、持 続的で合法的な木材供給量の3倍であった。

不幸にも、IMFと世界銀行に支援されインドネシア政府が従つた債務管理 政策は、大半の森林および紙パルプ企業を含む「戦略的な」企業に対する政 府による制御を素早く解除するのに好都合であった。これら企業の負債は、 加工容量低減の要求を課されることなしに、総帳簿価格の $20 \%$ 程度で販売 された。その結果、公的資金から解放された企業は、非持続的な操業を継 続、時として拡大することさえできている。

(Setiono、2007) 
森林としてではなく別の土地利用(たとえば家畜の放牧)のほうが長期的によ り利益があると見なされる場合には、個別の所有権の保証が森林から他の土地 利用への転換を加速する方向に働くことがある(Wunder、2000; Kaimowitz、 2002)。このことは、持続的森林管理は、その前提条件と見なされている土地に 対する安定かつ予測可能な権利の保証と、森林保全は収益性に劣るという根本 的原因に対処する経済的動機づけがあわせて適用された場合にのみ達成可能 となることを強調する。

国有森林資源の配置もしくは転換に関する不透明な意志決定、それにともなつ た利権あさりの行動は、森林減少と森林劣化を引き起こす二番目に重要な要因 である。不明瞭もしくは重複した法律と条例、担当部局間で交錯した権限、そして 不完全な地方分権の導入による混乱、これら全てが、企業家が森林保護の制度 を巧みに回避し、「グレーゾーン」を食い物にする機会を提供する。インドネシア においてCassonとObidazinski(2007)は、2000年に始められた地方分権化に むけた改革が、合法および違法伐採の区別の曖昧さを引き起こしたことを見いだ した。新しく権限を与えられた地方役人が、追加的な歳入を求めて、小規模で管 理の乏しい伐採コンセッションに許可を発行し、かつては違法な活動とされたも のを合法とした。

同様に国家経済と政治のエリートは、森林資源への経済支配を強めるために その強大な地位をしばしば使い、非持続的な採取に寄与している（Barr、1999; Colchesterら、2006; Milledgeら、2007)。政府役人や軍人と密接な繋りをもつ 木材および木材加工企業は、価值の高い伐採および植林コンセッションの有利 な入手手段を得て、それらに関連する経済利権の著しい分け前を獲得すること ができる(Barr、2001)。多くの木材生産国における全ての段階での污職の蔓延 は、しばしば強力な政治と企業関係者が最低レベルの公共の説明責任すら持た ないことを許す。国内そして国境を越えたこのような「エリートによる搾取」の機 会は、紛争状況下において、より悪化させられる(Bakerら、2003; UNSC、2002)。

第三の統治要因は、森林の運命にも影響する不適切な法律と脆弱な法執行能 力である。森林法はいくつかの持続可能な森林活動を違法とすることがある一方 
で、他の非持続的な活動を合法とすることがある。Colchesterら(2006)は、森林 法が貧しい人々の森林に基づく収入源を違法とし、その一方で林業部門外の法 律は住民共同体の権利を保護するには脆弱なことが多く、不明瞭もしくは無視さ れる傾向があることを見いだした。また同時に、森林法は大規模森林犯罪をとり あつかうためには、弱い法的手段であることが確認された。インドネシアでは、悪 名高い個人および企業に対する違法伐採・火入れの訴追が、うまくいかなかった (Smithら、2007)。

\section{その他の要因：}

・ 文化要因：地域の文化は土地に対する利用に直接影響する。例えば、神聖 な森林はしばしば土地転換と森林減少から守られる。しかし、他の文化要素 は森林に圧力をかけることもある。例えば中南米の「カウボーイ文化」は、高 い食肉消費と放牧地の設立を目的とした多くの森林開拓をともなっている。

- 人口動態要因：農村人口の増加と農業フロンティアへの移住は森林開拓に 利用可能な労働力を増加させる。都市と農村の人口増加もまた、食料と他の 生産物に対する土地需要を上昇させ、それらを生産するさらなる土地が必要 となる。このことは、森林減少のほとんどが森林の農地への転換一その大半 は小規模でなく産業化された農業一によるという観察とともに示唆しておく 必要がある。

・技術的要因：技術の改良は森林減少速度に影響することがある。例えば、 土地拡大技術の適用は、森林を犠牲にした農業の拡大を招くことがある。も しくは、より集約的な新しい農業技術は、森林フロンティアにおける粗放な 農業から資金を引き上げ、森林減少を低減させることがある(Angelsenと Kaimowitz、2001; Angelsen、2007; Chomitzら、2007)。森林減少に対する 農業技術向上の意義は一般に不明瞭で、二つの相反する力の相対的な強さ によって決まる。新しい技術は第一に、それが収益性を高める場合に導入さ れ、農業利益の高まりは森林の転換をより魅力的なものとするだろう。第二 に、生産物供給(そして労働者などの投入の需要)の増加は収益性の増加を 鈍らせる一ことによると逆転させる一方向に、価格を変えるだろう。眓2は正味 の影響を決定する重要な要因を示す。 


\begin{tabular}{|cc} 
森林減少への影響 \\
労働および資本の集約 \\
\hline 強制的 (高) \\
\hline 農業従事者の性質
\end{tabular}

\section{図2：農業技術と森林破壊との関係性 (AngelsenとKaimowitz、2001)}

\section{4 将来のREDD制度に対する示唆}

森林減少と森林劣化の原因に関するさまざまな研究の要約から、森林の利用 と転換という単純な活動の背後には、社会、経済、そして政治の現実という複雑 な組み合わせがあることが明らかになった。しかし、多次元的な原因要素は国 ごとにそして時代によって大きく異なるため、これを一般化することは困難であ る。このような複雑性と多様性は、異なる発展段階にある異なる国々における REDD体制の計画と実施には、「ひとつが全てに当てはまる」手法がないことを意 味する。研究はまた、様々な潜在的な原因一為替相場の変動といったマクロ経済 要因、地方分権化といった統治要因一の森林に対する正味の影響は、予測困難 であることを明らかにした。つまり、REDD政策が森林保護の推進という目標を達 成するかどうかは、本質的に不確実なのである。

森林減少を低減するための政策改革への動機づけは重要であるが、一方で森 林減少の影響を定量化するのは非常に困難である。研究が示唆するのは、炭素 クレジット方式の報酬は、個別政策の実施に対してではなく、国家(もしくは準国 家)レベルでの定められたベースラインと比べた森林減少の低減と関連づけられ るべき、ということである。 
森林減少と森林劣化の潜在的原因の第一のグループは、森林保護のための 直接的な政策介入に影響されない広い意味での経済的・社会的条件一たとえ ば、物資の価格、農業の技術、そして人口動態の傾向一に関係している。この ような原因による影響の分析は、森林に対する圧力を予測するのに主に役立 ち、予防手段の適用を促す。

森林減少と森林劣化の直接的および間接的原因の第二のグループは、経済 成長と貧困削減を達成しようとする社会と政府の志向に関係している。多くの 場合、森林から他の土地利用への転換は発展途上国にとって国家の富を増大 させる重要な段階である。特に重要なのは農業の拡大だが、居住政策、森林 産業への投資、農村部におけるインフラストラクチャー開発、バイオ燃料開発 などもそれらの手段である。REDD体制を成功させるためには、説得力のある 経済的選択肢を提供する必要があり、そしてまた多様な産業分野間を横断し た調整が必要となる。

森林減少および森林劣化の直接的および潜在的原因の第三のグループは、 政治的および経済的エリートの利益に関係している。この利益は政策立案者 にとって今日に至るまで森林保護の達成よりも優先事項である。このような利 益は、当局が伝統的森林利用者の所有権も保証せず、森林産業に対する適切 な取り締まりも行わず、森林法の改革も執行も行わず、森林に関する意思決定 の不透明さもなおざりにしたお陰である。地球規模でのREDD体制確立への期 待が、これらの原因に取り組む統治改革の進行を加速させるためのきっかけ となるかどうかが問題である(Chomitzら、2007)。

統治改革は幾重にも魅力的である。例えば、伐採やアブラヤシ、大豆生産の ためのコンセッションおよび土地利用計画に関連した政策変化を通じて、森 林減少の低減に及ぼす影響は大規模になることもありうる。何百万戸もの小 規模農家を巻き込む改革と比較して、取引費用は小さい。そして、このような改 革は貧困削減のような他の政策目的に対してあまり競合しないものである。

（訳 御田成顕） 


\section{森林減少と劣化の削減 のための政策選択}

本章では、第2章で示した森林減少と劣化に関する傾向、第3章でとりまとめ たそれらの潜在的原因に対処するための政策選択を提案する。

十年前、Kaimowitzら(1998)は森林減少を防ぐための政策について徹底 的な分析研究に着手した。その研究は、「適切な」森林減少と「不適切な」森林 減少の規範的な区別を提案した。「適切な」森林減少は、実用性の低い森林が より高くもしくはより長期的な利益を得ることができる土地利用に転換された 場合のように、森林の開拓が開発目標を支持するという認識に由来する。「不 適切な」森林減少は、森林の重要な価值を犠牲にし、ふさわしくない土地利用 に転換した場合に起きる。生物多様性の高い土地や、森林に依存して生活す る人々の多い土地、もしくは森林転換が結果的に「下流」に悪影響を与える環 境的に脆弱な地域において、森林減少は不適切であることが多い。

実際には、多くの利害関係者の関心が森林減少とそれを食い止めようとす る試みの両方に影響されるため、適切な森林減少と不適切な森林減少の区別 が曖昧であることがしばしばある。確かに、気候保護の狭い視野からはどのよ うな森林減少も劣化も好ましくない。なぜなら、これらは気候変動を引き起こ す温室効果ガスを放出するからである。地球規模のREDD体制の導入は、ある 特定の場所においてどのような森林利用が最も適切であるのかという判定方 法を修正すると期待される。代替的な土地利用により何を得て何を失うかに 
関する入念な考慮は、どこでどのようにREDDを実施するかという政策決定の 重要事項であるべきである。

Kaimowitzら(1998)の分析は、以下のような形態の政策が森林減少速度に 影響すると結論した。

・熱帯の農林産物の価格および需要の規制

・森林減少をともなう生産のコストとリスクの増大

・ 土地投機の抑制

・ 森林維持の採算性の向上

・ 森林の開拓に使われる資本および労働の機会費用の増加

以下では、バイオ燃料投資の急増、違法伐採対策への国際的関心、環境サ ービスに対する支払い(Payments for Environmental Services: PES)計画の 経験といった、過去十年間にわたって生まれてきたいくつもの動きに配慮した 上で、これまでの分析を基礎とし新たな分析を加える。森林減少をなくすため の動機づけと政策手段に関する文献の再検討は、経済・財政的手段、直接的 な規制、管理と制度的強化、を区別した分類を提案する。

\section{1 経済·財政的手段}

第3章で説明したように、森林開拓の根本的な原因は、個人土地所有者にと って森林を保全するよりも代替的な土地利用の方が利益が大きい傾向にある ことである。経済・財政的手段は、土地利用の意志決定者が森林保全から得ら れる相対的な収益および利益を反転させるために用いられうる。経済的な観 点から、このような手段は森林減少に伴う負の環境的影響、もしくは森林保護 の正の外部性を、価格に組み入れる。関連する政策は二通りある。一目は、 伐採、火入れ、農地転換、そして森林への入植からの収益、などを人為的に上 昇させる補助金およびその他の価格を歪める政策の廃止に関わるもの、二つ 目は、森林を保護することに正の動機を生み出す、新しい市場と金融メカニズ ムの創造に関わるもの、である。 


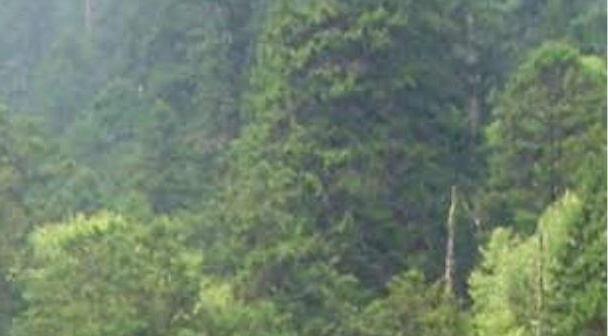




\section{森林減少と劣化を促進する補助金の廃止：}

森林減少を引き起こす活動の費用とリスクを軽減させる補助金は、それ により森林減少を助長している。森林減少と劣化を低減させるための政策 選択の第一歩は、このような補助金を廃止することである。Kaimowitzら （1998）とWunder(2003)は以下の事項を特定した。

・ 農地拡大を促す農業投入に対する補助金

・ 入植および入植計画に対する金銭的補助

- 新しい開墾地での活動に対する技術的・助言的な支援、税額控除、 補助金

・ 粗放的土地利用分野(特に家畜放牧)での輸入制限

・ 道路と輸送に対する補助金

・破壊的な開発に従事する伐採抢よび森林産業への支援

しかしながら、農業補助金の廃止だけでは森林減少を抑制するには 十分ではない。ブラジルと中央アメリカの場合、畜牛の牧畜への補助金 が廃止され、森林減少は一時的に収まったものの、その後再び増加した (Box6)。

\section{Box6: 補助金の撤回が不十分になる時}

Kaimowitz(2002)は、家畜貸しつけ補助金およびその他の政策が アマゾンの森林減少に対する影響を、再検討した。農業活動に対して 与えられるいくつかの補助金が撤回された後、1987年から1991年に かけて、森林減少は低下した。しかしながら1990年代に伐採がより強 度になり、たとえ補助金無しでも農業と家畜の放牧が儲かることがは っきりすると、森林減少は再び増加した。いくつかの事例では、土地に 対する権限を保証することは、農民が森林減少を増加させる活動を実 施するための貸し付けを受けることを助けていた。これらの知見は、森 林減少を止めるための政策は、複数かつ動的な森林減少の潜在的原 因が理解され正された場合にのみ、機能することを示唆している。 
補助金による農地拡大を通じた森林への新しい圧力が、オイルパーム、 サトウキビ、ジャトロファ (jatropha)を含む「バイオ燃料」の開発として、現 れてきた。皮肉なことに、バイオ燃料一化石燃料に代わる環境に優しい代 案一の生産と使用を促進する現在の政策は、直接的もしくは間接的に天 然林の転換を刺激し温室効果ガス排出を増加させるという、思惑とは裏腹 な効果をもつかもしれない。EUおよびその他の国々で採択されているバイ 才燃料の普及を促進するという目標一実質的には補助金一は、REDDの目 的という視点から見直されなければならない。

例えば、アメリカ合衆国とヨーロッパにおいてガソリンとディーゼル燃料 の10\%をバイオ燃料に置き換えるとすると、それぞれ現在の農地の $43 \%$ と38\%の面積が必要となる(RighelatoとSpracklen、2007)。このような目 標が導入、維持されるならば、熱帯においてバイオ燃料生産を拡大するた めの圧力は増大するだろう。一部の事例では新しいバイオ燃料作物は荒 廃地において育てられるかもしれないが、それ以外の多くの場合ではバイ 才燃料開発は全体的な農地需要一単独では最大の森林減少の原因一を 増加させ、その結果、高いレベルの森林減少につながるであろう。

一方、1990年代に大多数の発展途上国で一人当たりの植物油消費 量が大幅に増加した。例えば、インドネシアとインドの消費量はそれぞれ 65\%と94\%上昇した(Murphy、2007)。この増加は、世帯収入の増加が 食生活を改善しより多くの食用油を使えるようになったことと密接に関係 している。食用としての消費であれ、バイオディーゼルへの転換であれ、パ 一ム油への需要は急速に増加し続け、すでに一般的な植物油価格に影響 を及ぼし始めている。「バイオディーゼル効果」は、多くの国々における新 しい事業の拡大と共に、パーム油市場を歪ませている(Murphy、2007)。 2004年にオイルパーム栽培のために覆われた地表の面積は世界中で 899万haと推定された。2007年までにこの值は 1 ,092万haに増加した （Carterら、2007）。たとえバイオ燃料生産への補助金がなくとも、多くの 国の森林はオイルパーム開発によって劦威にさらされ続けるであろう。そ のため、「不適切な」森林減少を生じさせない開発であることを確認する、 他の政策手段が必要となる。 
木材採取に関しては、より一般的な利権政策改革の一環として、人為的に低 く設定された立木伐採権料を上げる必要がある。しかし、低い手数料は木材 企業と林産業が享受してきた数多くの直接的・間接的な支援の一つでしかな W。

ここ15年の間に、アジアの紙パルプ企業のいくつかは、天然林をパルプと 紙に変える持続可能性のない事業に対して、融資や保証を簡単に得てきた。 Box5で示されたように、これらの企業の多くがアジア通貨危機の余波で債務 不履行となり、負債を国際銀行業界と影響を受けた国々の国民にうまいこと 転嫁した（Barr、2001）。財務詳細調査一提案された処理能力の拡大が合法 的で持続的に調達された木材の供給を受けうることを確認するため一の増加 は、このように隠された補助金に注意を促し将来的には抑制することができる だろう。しかし、銀行によるリスク評価と詳細調査だけでは、非持続的なパルプ 生産者への融資を断るのに不十分なことを、Box7は示唆している。

\section{Box7: 森林投資の金融リスクに関する過小評価}

CIFORが2006年に実施した国際的なパルプ工場への融資に関する研 究は、銀行およびその他の投資機関がパルプ工場事業に関連する投資リ スクを過小評価しがちであることを見いだした。特に新しいパルプ工場や 容量増大事業に対する繊維供給の持続性に関する適切な評価について、 投資機関は繰り返し失敗していた。大半の銀行は内部に林業の専門的知 識をもっておらず、事業のうち森林施業に関わるリスク評価を一世界銀行 の国際金融公社のようなー多数国参加の金融機関に依存する傾向があ つた。

一般に投資機関はリスク管理のため分散投資手法をとる。この場合、個 別の融資の検討よりも産業部門や国の構成を重視する。さらに、リスク評 価は概して、格付け機関による借しつけリスク等級を基礎としている。仲 介排除と競争激化の状況で、貸し手や投資家は特定の企業についてのよ り詳細な信用評価を可能とする明快で適切なデータを入手する方法をし ばしばもたない。

(Spek、2006) 


\section{森林保護のための新しい動機の創出：}

市場の失敗は、森林の減少と劣化がこれほど激しいことの主な理由のひと つである。森林は、価值に対する支払いのない財やサービスを、正しい意味で の「土地利用者」が受け取っているよりもずっと多く提供している。このことは 社会が天然林の保護を他の土地利用への転換と比べて過小に評価する原因 となっている。経済・財政的動機とは、価格シグナルを通して、また森林を転換 もしくは劣化しないことで失われる利益を補償することによって、個々の土地 利用者の決定を変更するための手段である。例えば、以下のようなものがあ る。

・ 森林が保全されている土地に対する税率の低減を含む森林に配虑した 支援。

・ 森林の減少と劣化を最小限にする方法で生産された林産物に対して市 場シェアの増加や価格プレミアムを用意するという、消費者の選好に依 存する認铻制度。

・ 有益な活動や森林保護に有害と考えられる活動を排除する公的もしく は私的な投資の流れ。例えば、非木材林産物の商品化のように、森林を 開拓しない活動を支援する小規模金融計画により、公的機関は財源を 土地所有者が利用可能なものとできる。また一方で、木材供給において、 社会的、環境的、法的な予防手段基準の遵守を示すことができない森林 産業、もしくは大規模な森林の開拓を必要とする活動に対する公的およ び私的な投資の流れは否定されうる。

・移転支出計而は、ある特定の行動を行った場合に対して（例えば、植林 もしくは天然更新)、または行わない場合に対して(例えば、森林の開 拓もしくは伐採)、限定的かつ条件付きの補償金を与える。具体的な基 準によって森林事業者に対して割り当てられている基金を通して、財源 は分配される。例えば、「環境サービスに対する支払い(Payments for Environmental Services: PES)」計画(Box8)や自然保護債務スワップ (Debt-for-Nature Swaps: DNS)などが含まれる。コスタリカとメキシコ におけるPESの事例研究は、環境サービスを提供する土地利用者に対し 直接補償できることを示している。補償計画は、より安定した土地保有権 もしくは公共サービスへのアクセスといった、非金銭的収益として考案さ れる可能性もある。 


\section{Box8: 環境サービスのための支払い}

「環境サービスのための支払い (Payments for Environmental Services: PES)」は、新しい保全方法論の一部で、補償的な支払いにより 土地所有者と他の受益者の利害を繋ぐことの必要性を、明白に認識して いる。PESの仕組は、明確に定義された環境サービスと、最低限一つの売 り手と一つの買い手をもつ、自発的で条件つきの取り引きといえる。条 件つきーそのサービスが実際に提供されたときにのみ支払いがなされ ることを意味する「実務的原則」一はPESの最も革新的な特徵である。

炭素排出削減からの利益により土地所有者に森林減少を制限させる 支払いは、PESの一例である。REDDに由来する四つの環境サービス、炭 素の吸收と蓄積、生物多様性保全、水源保護、景観の美しさ、はPESによ る対象となりそうである。

PES制度の計画は、明確なベースラインの設定、環境サービスの「売り 手」が直面する機会費用の計算、そして組織的能力に応じた支払い手順 の必要性、に注意を払わねばならない。さらにPESは、土地利用を効果的 に支配し、その決定が移転支出からの利ざやにより影響を受ける実施者 を対象にしなければならない。

PES制度のほとんどは現在、先進国で見いだされ、それらの大多数が 民間セクターによるものではなく政府の実施によるものである。発展途 上国では、需要側の支払い意欲の欠落と供給側の実施能力の欠落によ り、PES事業の開発が妨げられてきた。

(Wunder、2007) 


\section{2 直接的な規制}

前述の経済・財政的手段の適用は、安定した森林保有権と森林資源の管 理能力を持つ森林管理者の肩にかかっている。多くの森林地域において、こ のような条件は当てはまらず、森林の所有権と利用権が争われている。その ような場合、森林利用に対する直接的な規制は、非常に少ない実行可能な 選択肢の一つかもしれない。

直接的な規制は、通常「指揮統制」と言われ、森林行為者の行動を導く法 律と規制の制定と実施に関係する。直接的な規制は環境政策および土地利 用計画の最も一般的な形態である。国立公園の制定、伐採や火入れの禁止、 土地利用区分などにより、森林の転換と劣化を違法行為とすることで、直接 対処できる。

直接的な規制は、森林保護もしくは減少という傾向に顕著な影響を与える 政策変更の機会を提供する。道路建設と土地開墾との間には強い関係があ るため、輸送インフラの計画と設計は特に重要である。Chomitzら(2007) に よると、「政策による管理の下では、道路による接近を可能とすることは、森林 減少に最も影響のある決定要因である」。さらに、前章で示されたように、伐 採コンセッションの施業にとって、また木材加工産業が合法で持続的な供給 による木質繊維を調達するのを確かにするという点で、森林産業に対する規 制には改善の余地がある。

国立公園のような保護地域は現在世界の森林の7分の1を占めており、そ の数は過去20年にわたって急速に伸びている。Chomitzら (2007)が再評 価したように、それらの有効性は、役に立たない「紙上の公園」から有効な 「保全の手段」まで様々である。しかし一般的に、保護地域内における森林 減少は、保護地域の外よりかなり低いという傾向がある。ブラジル、コスタリ カ、マダガスカル、ウガンダは、国立公園が森林減少を低下させた国々の例 である。保護地域の有効性は、活動費用の甚だしい不足によって、しばしば 下げられる。REDDの枠組みは、新しい保護地域の創出に貢献するだろう。も し事前に設定されたベースラインに対する炭素蓄積保全の改善が見込める 
なら、場合によっては既に設定された保護地域の管理費用にもREDDの支払 いを充当できるであろう。

\section{規制による予期せぬ負の結果の回避：}

不適切な規制は、森林の減少と劣化を防ぐ役目を果たしている活動を不 用意に抑制する。例えば多くの国々で、非木材林産物の採取、輸送、販売に 関する規制は、木材のために制定された規制を不適切に真似ており、極端に 高い費用を小規模生産者に課している(BelcherとSchreckenberg、2007)。 しかし、非木材林産物の商業化は森林から他の土地利用への転換を妨げる ことの一助となる(Kustersら、2007)。経済・財政的手段として上述した道理 に反する補助金と同様に、森林減少と劣化を管理する第一歩は道理に反す る規制を取り除くことのはずである。

近年、森林フロンティアにおける限られた政府の影響力もしくは污職とえ こひいきが、直接的な規制の効果的な施行をしばしば妨げるという認識が 高まったことから、直接的な規制という手段から離れる事例の増加が認め られる。確かに、複雑すぎる規制は污職の機会を増加させると、よく引き合 いに出される。直接的な規制の有効性は、現存する法の明快さと適応性、政 府もしくは地域共同体のような他の利害関係者による、違反の報告、法の執 行、非遵守への処罰、などの能力に、強く依存している(Gregersenら、2005; Colchester 5、2006)。

公平という点では、現行の森林法の施行強化には、小規模森林利用者を 処罰する一方で、森林減少を引き起こす最も重要な関係者を見逃す、という 危険性がある。Colchesterら(2006)は、5力国における事例研究によって、森 林法施行強化は地域の貧しい人々を取り締まりの対象にする一方で、森林 犯罪の背後にいるより大きい権力をもつ実業家の自由な活動を許すという、 小規模森林利用者に不利な作用をする傾向があることを見いだした。この 不公平性を解決するための一つの方法は、大規模な違法行為を促進する犯 罪を当然の標的とする、法執行手段を用意することである。このような手段に は、違法伐採の事例に含まれる資金洗浄や污職行為に関する追跡の遂行を 含む(SetionoとHusein、2005)。 


\section{規制に対する国際的な制限：}

過度の森林開発に対処するための国家レベルの政策選択は、国際的な 貿易投資の合意によって制限されている。例えば、通商ルールに認められた 優先性のために、違法な木材製品の国際貿易を消費国において取り締まる 規制的な手法は不可能であった。その結果、欧州連合による森林法施行強 化と統治执よび貿易のための取り組み (the European Union’s Forest Law Enforcement, Governance and Trade; FLEGT)の活動計画は、WTO(世界 貿易機構)協定の規制を逸脱しないように、自発的な二国間認可計画に限 定された。Humphreys(2006)によると、地球規模での「新自由主義」の容認 が、国連森林フォーラムとそれに先行して繰り返された国際会合における何 年にもわたる議論にもかかわらず、国際社会が森林の減少と劣化という難問 に対処する効果的な体制の創出に失敗したことの主たる原因である。

\section{3 統治機構と組織的能力の強化}

強い統治機構と組織的能力は、経済・財政的手段と直接的な規制の両者 の効果的な設計と実施を支えるために必要である。保有権と所有権、意志決 定手続きの透明性、そして有能な組織という、三つの分野が森林減少と劣化 の原因に対処するため、特に重要である。

\section{保有権と所有権：}

第3章で述べたように、土地保有権の体制と所有権は土地の利用方法に 強い影響をもつ。多くの熱帯諸国では、土地所有権は開拓された土地の「利 用」についての公的な定義によって決まるので、積極的利用」を通して土地 私有権を強化したり、没収を避けるために、森林開拓を後押ししている。この 「森林減少による入植」の仕組みは、次々と森林を伐り払う人々にのみ安定 した土地保有権と所有権を割り当てることにより、非公式(例えば、隣人や外 部からの居住者は「利用されている」土地に対する主張をよりたやすく認め る)でも、政策しベルでも、存在しうる。森林減少を制限する第一歩は、所有 権の確立と確保のために森林伐採を必要とするという所有形態を排除し、土 地に対する権利の確保と森林減少の繋がりを効果的に断つことである。 
最も有益で長期的な森林資源の利用に対する投資を行わせるための動 機づけを民間の行為者に与えるものとしても、明確に定義された所有権は 必要不可欠である。森林保全が実質的に個人として最も有益な土地利用 の一部をなす場合には、所有権を確立することでより持続的な管理を導く ことができる。森林転換の機会費用が高い場合、持続的な森林管理を条 件として形成される保有権の保証は、環境サービスに対する「現物」支給と いう形で利用することができる。この戦略は現在、「東南アジアにある高地 の貧しい人々に対する環境サービスへの報酬 (Rewarding Upland Poor for Environmental Services: RUPES)」の調査地において試されている (www.worldagroforestrycentre.org/Sea/)。

ブラジルの採取可能な保護区に例示されるもう一つの新制度は、転換を 避け土地投機に対抗するための、持続可能な森林管理に関係する規制を伴 つた地域共同体による所有体制の確立である。また別の例は、私有保護林ネ ットワークの奨励である。これは、収入増加と財産侵害防止のための協同的 な支援の役割を果たし、近年、中南米地域で急増している。ししながら、こ のような革新的戦略は、森林の状態の監視(モニタリング)と連動しなければ ならない。

\section{意志決定手続き上の整合性：}

これまでの節で示したとおり、これまで森林部門の統治は公共資源のトッ プダウン的で不透明な配分が特徴であり、それによりしばしば森林減少と劣 化を回避するという公共の利益が犠牲となってきた。森林に関連する意志決 定手続きの整合性を改善することにより、広範囲の利害関係者の利益に配 慮できるようになるだろう。

情報へのアクセスと森林に関する意志決定の透明性の向上により、公益に ついての有権者の発言権は強化されるだろう。個人と政策立案者が合理的 な決定をするならば、時を得た信頼できる情報を利用できるようにすること で、彼らの交渉能力と適切な意志決定能力が強化される。透明性により、污 職の機会は減り、政府機関や民間企業が責任ある森林管理をしているかど うかを一般市民や公益組織が監視しやすくなる。森林の状態および動向や 
状態の変更案(たとえば農地への転換)に関する情報により、合理的な土地 利用の決定が行われやすくなり、エリートが決めた政治的色合いの濃い法 令に対抗する市民活動を起こしやすくなる。森林産業による施業情報開示の 強化は、消費者および規制の両方の意思決定に情報を与えることができる (Barr、2001; Spek、2006)。

リモートセンシングと情報の一般公開に基づく新しい手法は、森林減少を 抑える仕組みの効率性を改善してきた。例えば、Chomitzら(2007)は、大規 模な地所の位置を登録し土地利用規制を遵守しているかを追跡するリモー トセンシングを利用したシステムの導入が、ブラジルのマト・グロッソ州の土 地所有者の行動を違法な森林減少を抑制する方向に転換させたことを報告 している。

意思決定への包括的な参西によって、森林政策の設計と実施の両方を改 善することができる。森林に関する意思決定は、広範に有益だが危機に瀕し ていることが多い生態系サービスと財政収支に関係しているので、一般市 民にとっても重要なものである。ししながら、森林の中および周辺に位置 する共同体は、森林減少の犠牲者であるか純粋な受益者であるかに関わら ず、彼らの利益が森林管理の変化によって最も大きく影響される可能性があ るので、森林に関する意思決定に特に大きな利害を持つ。さらに、彼らの協 力が多くの森林に関する政策の実施において重要である(Colferら、1999; Purnomo5、2005; Colfer、2005)。

\section{有能な組織：}

政策を設計、実施、そして執行する政府の能力は、それらの効果を確実に するための鍵である。国家、地域、地方レベルのそれぞれに、適切な責任とそ れを全うするための資源を確実に配分することで、それぞれのレベルの能力 を伸ばすことができる。

前述の所有権の重要性に関する議論に関連して、森林資源に対する地 方の権利を強化するために計画された森林保有権改革という近年の潮流 （Wily、2004; www.rightsandresources.orgも参照のこと）は、将来の組織 
改革と取り組みの強化を構築するために有用な経験を与える。不十分な権 限の委譲、権利と使用権の分配における污職、公式もしくは非公式な利益の 継続に対する政府機関による過度の要求、そして所有権の保証を組織強化 と最小限の環境基準に調和させることへの失敗、によって多くの改革が妨げ られてきた(Ribot、2002; Oyonoら、2006)。所有権の本質的な委譲を支援 する政策、それに伴う資源の地域的な統治(例えば、権利と責任についての 明確な規則、監視システムと制裁)への支援、そして正しい動機づけは、より 効果的な成果を後押しし長続きさせるだろう。

住民林業事業および小中規模の森林企業は、産業的林業部門に比べ、持 続可能な森林管理また特に貧困削減という利益に対して、より見込みのあ る道筋を示すという証拠が増えている(Molnarら、2004; Mayers、2006; Chomitzら、2007)。しかしながら歴史的に、これらの利害関係者は持続的森 林管理を支援する役割に対して、政府の林業部局から十分な支援を受けて こなかった。共同体と先住民による森林管理事業権を成功させる支援の鍵と なる要素は以下のものを含む。

- 所有権と政治的権利の法的な保護

・ 共同体に商業的発展もしくは技術的支援を提供する中間的組織の強 化

・(「基準と指標」アプローチを基にした)共同体による適切な認証モデル

・ 共同体一企業間の協調関係の発展(El Lakanyら、2007)

\section{4 将来のREDD制度に対する示唆}

上述の政策選択に関する分析は、国家レベルのREDD戦略の設計と実施 のために、次のような示唆を与える。

第一に、国家のREDD戦略は、森林減少と劣化を促進する活動のコストとリ スクを軽減する、もしくは持続的な森林管理を支援する活動を妨げる、現行 の政策を廃止することに対して早期に注意を払うべきである。優先項目は、 農業、牧場経営やバイオ燃料開発をより儲かるようにする補助、そして持続 
的な木材供給を保証できない森林産業に対する投資リスクの軽減、を含む 森林開拓を促進する活動への支援を撤廃することである。非木材林産物の 利用に対する煩雑な許可手続きのように、小規模および共同体森林企業を 抑圧し污職の機会を生み出すような効果をもつ規制は、見直され修正され なければならない。

しかしながら、道理に反する支援と規制の排除だけでは、森林減少と劣化 を促進する多くの力を覆すには、必ずしも十分ではないだろう。例えば、バイ 才燃料に対する補助金がなくても、食用油としての消費によりパーム油に対 する需要は上がり続けるだろう。先行する他の利用のための森林転換の機 会費用が高い場合でも、森林減少が避けられるべきならば、正の動機づけ と直接的な規制を含む政策決定の組み合わせが必要となる。森林に関する 所有権が明確で保証された場所では、PES（環境サービスに対する支払い計 画)のような直接的な民間移転支出が土地所有者の行動を変える見込みを 示す。それ以外の場所では、REDD戦略は森林所有権を明確化するための初 期投資を必要とするだろう。

REDD戦略の文脈における直接的な規制の適用は、「不適切な」森林減少 を抑制する最も有効な機会を提供することを目的とし、特に地方の貧しい人 々に対する意図しない負の結果を避けるよう、注意深く実施される必要があ る。新しい道路の開発が脆弱な森林に対する接近路を開かないことを確実 にすること、産業規模の森林犯罪を対象とした法施行強化活動の推進、商業 企業による保護手段のさらなる遵守などが優先順位の高いものとみなされ るべきである。

REDDの支援における、新しい動機づけとよりよく対象を定めた規制の実 施は、引き続き新しい統治体制と組織的能力の創出を必要とするであろう。 例えば、透明性のある効率的な手段で資金の供給と割り当てを行う中間的 組織が存在し、支払いに対する見返りとして「売り手」の実績を確認する監視 (モニタリング)システムが整っている場合においてのみ、移転支出計画は 大きな規模の効果を持ちうる。産業規模の森林犯罪に対してより効果的に目 標を絞っても、司法当局職員の能力を強化する投資なしには、告発の成功と 
いう結果につながらないだろう。そして最後に、小規模および共同体林業へ 移行するためには、政府林業部局の側に適切な支援サービスを提供する新 しい技能が必要とされるだろう。

（訳 岩永青史）

(n)

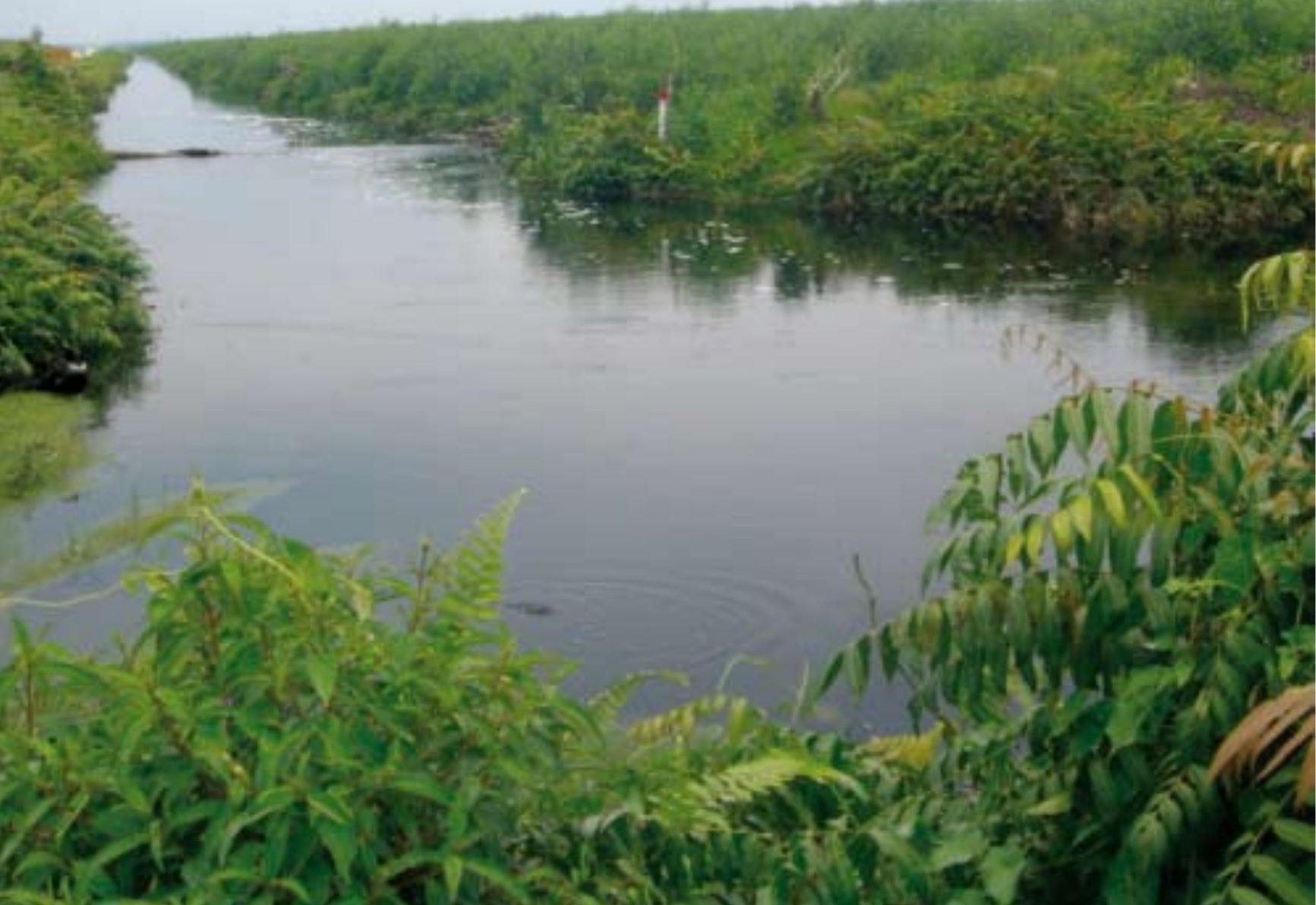




\section{REDD支持政策と今後 の研究に対する示唆}

森林減少と森林劣化は、社会的、経済的、環境的そして政策的な要素が入 り組んだ関係に起因する。森林減少や森林劣化の原因を一般化したり、全般 的に適切な対応を提案するのは困難である。したがって、どんなものにも対 応する唯一の解決策はほとんどない。異なる地域は、異なる直接的また潜在 的な森林減少の原因と、異なる対応能力に特徵づけられ、それゆえに固有の 状況に合わせた対策を要求する。

また同時に、問題は本質的に単純である。森林を保護するよりも別の活動 によってより多くの利益を得ることができる個人、団体もしくは政府の行為者 により、森林は他の土地利用のために伐り開かれたり劣化したりする。森林 減少や劣化の低減を目的とするどのような集団を対象としたいかなる戦略 も、この基本的な現実と取り組まねばならない。

国際的に提案されているREDD制度と現在議論されている国家による REDD戦略は一「補償」もしくは「奨励金」支払いのための一資金源を用意す ることで、この難問と取り組むことを提案している。現在の森林減少と劣化を 導いている費用便益の見積りを改めるための10年を越える研究からどんな 教訓が導きだされたか、それはREDDの議論に実際的な重要性を持つのか、 今後どのような研究が必要なのか?以下では、観測(モニタリング)と基準值 (ベースライン)、政策選択、制度的および統治的必要性について、課題と機 会を要約する。 


\section{1 森林炭素観測とベースライン}

第2章1節で示された森林被覆と森林減少速度に関する様々な推定值は、 現時点での森林観測能力が非常に大きな不確実性をもつことを示唆する。 森林劣化に関するデータはまたさらに信頼性が低い。REDD制度が想定され ているとおりに機能するには、よりしっかりした定義、体系および方法が、森 林の炭素蓄積の変化を観測するために必要となる。関係者の能力を強化し ながら信頼できるデータを収集、処理するためには、先進国と発展途上国の 協同作業が必要である。

しかしながら、第2章で示されたように、新しい技術はREDD制度により提 供される新しい報奨金とともに、REDD制度の開発を促進するために「十分 に優れている」と期待できる。地上での観察に支持された遠隔探査(リモート センシング)データは、効果的で経済効率のよい監視(モニタリング)の鍵で ある。そのために高解像度能もしくは非光学的センサーの利用は、データの 質と精度をあげることを必要とする。しかしながら現在、限られた2、30先進 国のみが、そのようなデータと、それを適切に受信、加工、分析する能力をも つている。まず必要なことの一つは、発展途上国における土地利用変化と炭 素蓄積データを分析する国家的能力と、その能力を向上させるための努力 を開始することである。熱帯地域の森林の炭素蓄積を定量化するには、より 進んだ研究が必要である。熱帯泥炭地および森林劣化に関連する問題を含 め、相違や不確実性が最も高いところに、特別な注意をはらわなければなら ない。

適切なREDDベースラインの決定においては、多くの不確実性と取りくむこ とが必要である。第2章1節で示したように、個々の国における過去の森林減 少速度の推定值は大きく異なり、そしてしばしば議論をおこす。さらに、次の 三つの理由により、過去の森林減少速度によるベースラインの作成は、注意 して行われる必要がある。

第一に、第2章2節で示したように、「森林の推移」に関する文献は、ある国 の森林減少速度が時間の経過とともに直線的に進む訳ではないことを示唆 している。国家発展の早い段階における森林の転換を加速する要因と引き 金に続き、森林被覆の安定化を支持する要因が役割を果たすようになる。 
第二に、異なる国およびある国の中の異なる地域は、森林の推移において非 常に異なった段階に位置する。国際的また国内の政策的議論では、このように 異なった出発点をもつそれぞれの支配権にまたがってREDDの資源を配分す る際、何が「公平」なのか決めねばならない。また同時に、本質的に森林減少を 減らすため、何が効果的なのか決めねばならない。その一方で、それぞれの国 に国家ベースラインに関する方法の開発をまかせるというのは、報奨金に見あ つた提案ではない。それぞれの国はより大きなREDD資源の移転が認定される よう、森林減少ベースラインをできるだけ大きく設定するという、直接の金銭的 動機をもつだろう。このように、信頼に足るシステムを構築するには、相互に認 めあえるREDDの方法論が必要である。

第三に、第3章で示したように、森林減少を引きおこす要因の多くは、国家 REDDプログラム (活動計画)により影響を与えるのが難しいものである。人口 増加、為替レートの動き、国際商品価格などは、森林に関する政策の対象とな りにくいものである。このためREDDベースラインに用いられる方法は、(たとえ ば、ある国家政府が森林減少速度と森林劣化を制御する能力など) 将来の変 化に非常に大きく不確実な範囲を含むようにする必要がある。

REDD制度が国レベルで実施されると仮定する場合、ベースラインの決定方 法に関する研究の最重要課題は次のものを含む。(a)過去の森林被覆変化の 分析とモデル化、(b)それらのモデルがあるREDDの枠組において、自然科学的 および社会経済変数の予測值をどこまで説明可能かに関する分析: (c) 国家べ ースラインを決定する際の地理的スケール(例えば国全体か国内の地域別か) の分析。

\section{2 政策的選択肢}

REDDの議論における政策選択のうちで最大の注目を受けているのは、破壊 的森林利用を森林保護に有利な行動に変えることを進める、個々の森林利用 者に対して直接支払いを行う可能性に関するものである。環境サービスに対す る支払い(Payments for Environmental Services: PES)に関する取り決めは、 炭素蓄積に対するもの単独であれ、他の森林による環境サービスをあわせた ものであれ、明らかに森林を減少させる決定を変えさせる可能性を提供する。 
しかしながら、第4章で議論したように、PESの枠組は、最低でも一人の実 行力のある「売り手」を特定できる可能性を含め、特別な状態においてのみ 実行可能となる。土地および資源利用に関する明快な権利が欠落した状況 で、PESの枠組もしくは別の経済的動機づけの仕組みを進めるのは、紛争を 引きおこしたりより権力の小さい主張者を周縁に追いやったりするため、逆 効果になるかもしれない。発展途上国にある大面積の森林は、事実上「誰で も利用可」体制にあったり所有権が争われていたりするため、支払いおよび 森林保護の失敗に対する責務の実行に先だって、明確な所有権そしてまた 利用権を制定する過程が必要である。

PESの枠組を有効で効率的で公平なものとするために必要な条件につい て、気候変動の制御といった国際的関心と、国や地方の利害を関連づけた研 究が必要である。複合的な環境サービス(たとえば炭素蓄積と水源保護の両 方)を枠組としてどのように統合できるかについても、さらに研究が必要であ る。REDD実証活動の努力は、そのような研究の「実験室」となりうる。しかし、 計画外の悪い結果が特定され対策がとられることを確実にするため、注意深 い監視と報告を活動に加えることが必要である。効率的でかつ紛争を最小化 し、森林に関する権利の明確化と保証を行い、最良の実施手法を明かにする ための研究も必要である。

効率的もしくは妥当な管理者がいない場所での森林減少を制御するため の努力は当面、取り締まりに大勢を頼らざるを得ない。第4章2節で議論した ように、それらの大半の事例は現在に至るまでほとんど成功してはおらず、そ れら自体が危険をもっている。排除的な政策の続行においては、自らを非効 果的で不公平なものとしがちな現行の法施行強化活動における弱点の改善 と、慣習的な森林利用を守るための努力がともに実施されねばならない。よ り良い法施行強化のため、政府公約と現場の協力をどのように要求するか の理解に向けた研究が必要である。国家間の比較研究は、どの手法が最も 効果的かについての指針を提供できるであろう(Tacconi、2007)。

第3章で提示された直接の支払いを補完するさまざまな政策変更は、森林 の転換と劣化の速度に無視できない影響をもちうる。事実、森林の喪失を減 
らすための第一歩は、不適当な森林減少を促進する現行の政策と制度をな くすことであるのは間違いない。その行動には、農地拡大、入植計画、森林地 域内での農園や道路の開発、などを含む森林転換の圧力を増す他の産業分 野に対する補助の撤回が含まれる。そのような政策の実施には、産業分野を 越えた省庁間の調整を必要とする。

林業部門においては、破壊的な伐採に従事する企業または過剩な木材加 工能力の設立に従事する産業に対する支援の撤回が、森林劣化を引きおこ す主要な要因に取りくむことになる。しいながら、現行の政策と計画による 既得の利益に打ち勝つためには強い政治的意志を必要とするため、そのよ うな政策改革の実行可能性は低いと判断される。森林資源に対して商業的 に接近している政治経済を、REDD実証事業に付随した新しい資金とその他 の動機付けがどのように変えうるのか、研究は明らかにできるだろう。

\section{3 制度と統治の必要性}

脆弱な制度と統治の環境は、残存する熱帯林をかなりの面積でもつ多く の熱帯の国および地方を特徵づけるものである。その結果、REDDに関する 取り組みの文脈であれその他であれ、森林減少と劣化を取り报うどのような 試みも、制度の創出と改革、統治過程の強化、森林管理の新しい模範(モデ ル)を実施する能力の向上、などの長期的な努力を組み入れる必要がある。 REDD計画の立案と実施は、有効性、効果性、公平性そして危険の配分に関 する折り合いづけ(トレードオフ)を必要とする。たとえば、(インドネシアの泥 炭湿地のように) 排出削隇に最大の可能性をもつところ、それとも貧困の出 現が最大のところ、を資源配分の対象とすべきなのか? 有力者が移転支出 の大半を獲得したり、資金が污職により失われたりする危険がある場所で、 REDDを進めるべきなのか?このような選択は政治的な決定であり、科学的 研究および経済分析は判断材料を提供することはできても、研究そのものが 政策を決める訳ではない。

森林資源を気候変動の緩和に最もうまく結びつけるにはどうするかに配 慮し、全ての適切な利害関係者の意味のある参加を可能とする速度でのみ、 
REDDは進むことができる。透明で包括的な意志決定を支持するためには、 適切な政府機関とその他の利害関係者集団による新しい政府の標準と技術 および実践が、必要である。

REDDの取り組みの実施は、意志決定手順の改善に加え、森林に関連する 権利と責任の明確化を必要とする。上で述べたように、移転支出の枠組を効 果的にするには森林に影響する能力と正当性の双方において、林地と資源 に対する権利が森林管理者の下で明確化され保証されねばならない。多く の場合このことは、森林資産を守る地域共同体の権利を強化し、森林火災の 制御、外部者に対する規制の強化、森林産物の搾取の制御、などの住民によ る管理活動に向けた地元組織との連携を増進することを意味する。地域住 民共同体と小規模生産者はより大きい行為者と同等の関係をもち、新しい REDDの仕組みを利用できるようになるための支援を必要とする。このような 取り組みの注意深い配列が重要になるであろう。適切な動機づけと制度無し の森林利用権の保証は、森林減少の軽率な増加を引きおこすかもしれない。

上で述べたような条件無しでのREDD活動の実施は、脆弱な地域共同体が より弱くされるという危険を引きおこす。よ強力な行為者が森林資源から の新しい炭素蓄積料を独り占めしようとしたり 4 、弾圧的な法施行強化の取り 組みが小規模の森林利用を対象とした場合、森林に依存する人々をないが しろにするという結果に終わるかもしれない。今後の研究が、公平性の関係 と管理の危険性に焦点をあてながら、REDDの目的を達成するのに最低限必 要な統治条件の解明をめざすのは、当然のことである。

森林減少や森林劣化が、違法な森林の搾取と商業規模の転換により引き 起こされるという点において、REDDの成功は数多くの改革にかかっている。 第4章で示したように、これらは、合法性の基準を明確化し正当化するための 法律と取りしまりの改革、森林犯罪を扱うための司法制度の強化、森林部門 における污職に対する寛容度を低減させる最高レベルの政治的要求、など を含む。さらに、違法に生産された木材製品に対する需要を含め、国境を越

\footnotetext{
4 例えば南スマトラでは、大きなアカシア植林企業と利益性の高い外部委託育 林方式による利益を得るために、新しい地主が生まれている。
} 
えて存在する森林減少の裏に隠された原因に取り組むには、国際的協力が 必要となる。欧州連合による森林法施行強化と統治および貿易のための取 り組み (the European Union's Forest Law Enforcement, Governance and Trade Initiative: FLEGT)によって実施されている様々な国および国際的な 活動を監視(モニター)する研究は、最も効果的な政策と手法に関する案内 （ガイダンス）を提供するであろう。

REDDで想定される移転支出の実施を政府が選ぶならば、その支出を透明 で効率的な方法で配分、管理する能力と正当性をもつ新しい制度の創設を 支援する必要がある。重要な課題は、その支出が森林で実際に起きているこ とを管理する立場にある地元の関係者に届くよう制度が計画されるようにす ることである。現在進行中のREDD実証事業により、どの支払い方式が効率 性を高めリーケージ(漏出)を最少化するのかを明らかにすることが、今後の 研究として必要である。

最後に述べるが決して軽んじられてはならないこととして、国と地方の組 織能力を向上させることがREDDの成功に必要であると、森林減少研究は示 唆している。必要な能力のいくつかは技術的なものである。例えば、当該する 省庁の職員は新しい炭素モニタリング方法に関する技術の開発、地域共同 体は火災予防方法の訓練、そして税関、財務および司法当局の職員は森林 犯罪と取り組む新しい能力、を必要とする。しかしながら最大の課題は、政府 機関の一部と同様に影響を受けている利害関係者集団の一部に、新しく制 度化した能力を構築することである。

国際的資金援助を現場での意義のある变化に移す統治の仕組みが無い かぎり、REDDの計画は効果的にはならない一つまりお金だけでは木は育た ない。国際的なREDD資金は重要である。しかし、明快な動機付けと森林減 少国政府による改革実施への強い公約により、補完されなければならない。

単に環境関連閣僚だけでなく、経済開発担当閣僚、政府の下部機関、住民 共同体および民間部門の関係者もまた、REDDに関わることの有利性を知る 必要がある。透明で包括的な意思決定過程が無い場合、将来のREDD支払 
いは受け取り国の有権者の間に森林資源をめぐる新たな紛争の種を作り出 すかもしれない。その代わりに意味のある合意形成過程は、変化に向けた国 内協調を助けうるかもしれない。持続的森林管理という上位目標を達成でき るよう「REDDを超える」目的を含めることで、そのような協調は強化されるで あろう。そして、豊富な森林を浪費する開発シナリオから、炭素蓄積を保護す る戦略に向けて、様々な関係者がともに働くことを可能とするであろう。

（訳 藤間 剛）

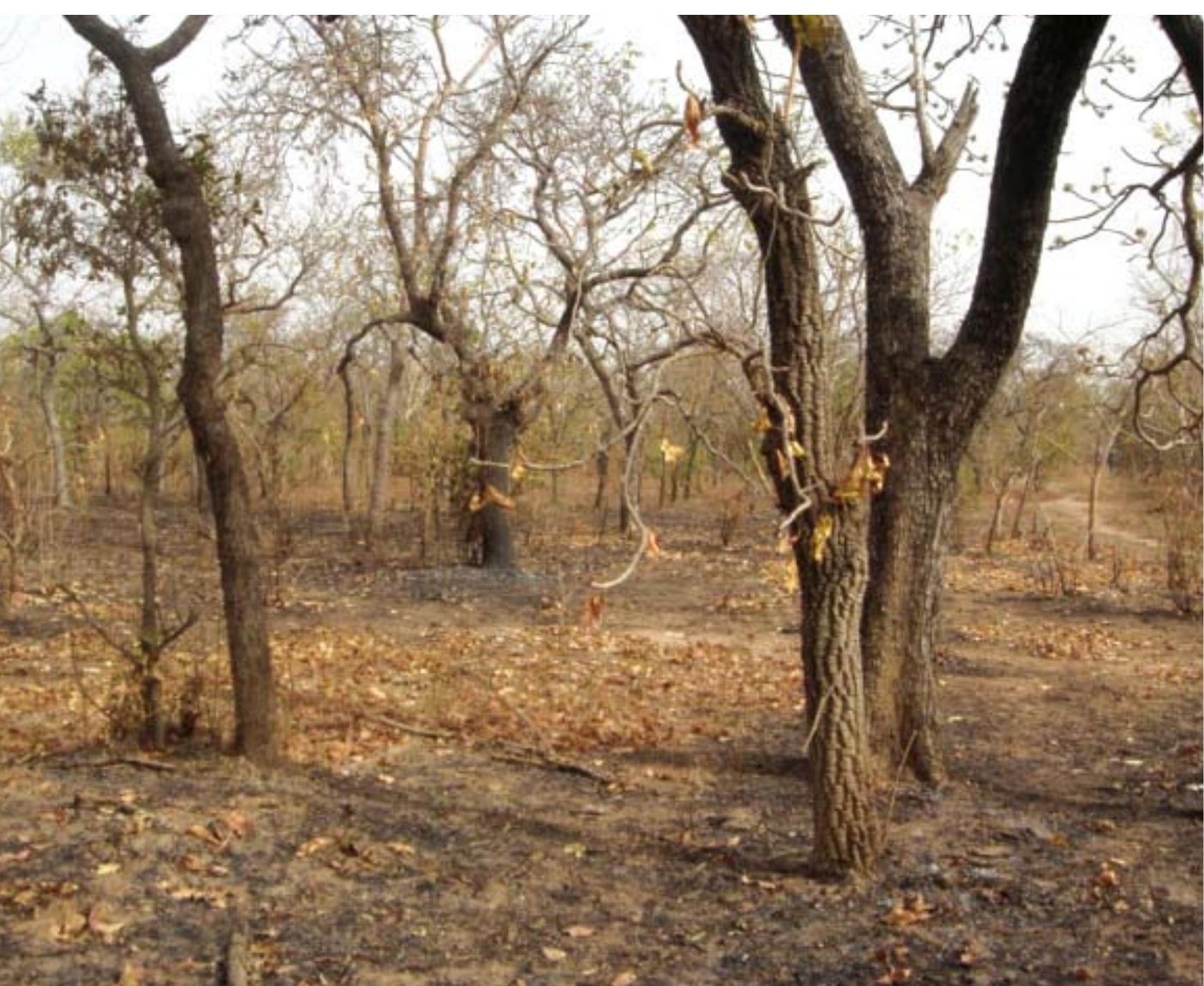




\section{引用文献}

[POLEX日本語版 (付録参照)で紹介された日付と表題］

Achard, F., Eva, H. D., Stibig, H.J., Mayaux, P., Gallego, J., Richards, T. and Malingreau, J.P. 2002. Determination of Deforestation Rates of the World's Humid Tropical Forests. Science 297: 999-1002.

Agrawal, A. and Ostrom, E. 2001. Collective Action, Property Rights, and Devolution of Forest and Protected Area Management. In: MeinzenDick, R., Knox, A., Di Gregorio, M. (eds.) Collective action, property rights and devolution of natural resource management: Exchange of knowledge and implications for policy. Feldafing, Germany: Zentralstelle fur Ernaehrung und Landwirtschaft (ZEL), Food and Agriculture Development Centre (DSE).

Angelsen, A. 2007. Forest cover change in space and time: Combining von Thünen and the forest transition. World Bank Policy Research Working Paper WPS 4117. World Bank, Washington D.C.

Angelsen, A. and Kaimowitz, D. 2001. Agricultural technologies and tropical deforestation. Center for International Forestry Research (CIFOR). Bogor, Indonesia, and CABI Publishing, Oxon, UK. 422 p.

Asner, G.P., Knapp, D.E., Broadbent, E., Oliviera, P., Keller, M. and Silva, J. 2005. Selective logging in the Brazilian Amazon. Science 310: 480482.

Aukland, L., Moura Costa, P. and Brown, S. 2003. A conceptual framework and its application for addressing leakage: The case of avoided deforestation. Climate Policy 3: 123-136. 
Awang, S., Purnomo, H., Wardhana, W., Guizol, P., Levang, P., Sitorus, S., Murtiyanto, N. and Susanto, Y. 2005. Levelling the Playing Field: improving partnership in pulp forest plantation to benefit the poor and reduce conflict. EU Funded LPF project report. Bogor: CIRAD, CIFOR, UGM.

Baker, M., Clausen, R., Kanaan, R., N'Goma, M., Roule, T. and Thomson, J. 2003. Conflict Timber: Dimensions of the Problem in Asia and Africa, Volume III: African Cases.

ARD, Burlington, Vermont. Barr, C. 1998. Bob Hasan, the Rise of Apkindo, and the Shifting Dynamics of Control in Indonesia's Timber Sector. Cornell University (Indonesia) Modern Indonesia Project, No. 65, p. $1-36$

Barr, C. 2001. Banking on Sustainability: Structural Adjustment and Forestry Reform in Post-Suharto Indonesia. WWF, Washington D.C. and Center for International Forestry Research (CIFOR), Bogor, Indonesia. 140p.

Belcher, B. and Schreckenberg, K. 2007. Commercialisation of non-timber forest products: A reality check. Development Policy Review 25(3): 355-377.

BisInfocus, 2006. Prospek Perkebunan \& Industri Minyak Sawit Di Indonesia 2006-2020, PT Bisinfocus Data Pratama.

Brown, S., Hall, M., Andrasko, K., Ruiz, F., Marzoli, W., Guerrero, G., Masera, O., Dushku, A., DeJong, B. and Cornell, J. 2007. Baselines for land-use change in the tropics: Application to avoided deforestation projects. Mitigation and Adaptation Strategies for Global Change 12(6): 10011026.

Bruner, A., Gullison, R.E., Rice, R.E. and da Fonseca, G.A.B. 2001. Effectiveness of parks in protecting tropical biodiversity. Science 291: 125-128.

Carter, C., Finley, W., Fry, J., Jackson, D. and Willis, L. 2007. Palm oil markets and future supply. European Journal of Lipid Science and Technology 109(4): 307-314.

Casson, A. and Obidzinski, K. 2007. From new order to regional autonomy: Shifting dynamics of illegal logging in Kalimantan, Indonesia. In: Tacconi, L. (ed.) Illegal logging: Law enforcement, livelihoods and the timber trade. Earthscan, London. p. 43-68. 
Chokkalingam, U., Suyanto, S., Permana, R.P., Kurniawan, I., Mannes, J., Darmawan, A., Khususiyah, N. and Susanto, R.H. 2006. Community fire use, resource change and livelihood impacts: The downward spiral in the wetlands of southern Sumatra. Mitigation and Adaptation Strategies for Global Change 12: 75-100.

Chomitz, K.M., Buys, P., De Luca, G., Thomas, T.S. and Wertz-Kanounnikoff, S. 2007. At Loggerheads? Agricultural Expansion, Poverty Reduction, and Environment in the Tropical Forests. World Bank, Jakarta, Indonesia. 284p.

[2007年2月15日付け 森林と貧困:そんな単純な話ではない!]

Colchester, M., Boscolo, M., Contreras-Hermosilla, A., Gatto, F.D., Dempsey, J., Lescuyer, G., Obidzinski, K., Pommier, D., Richards, M., Sembiring, S.S., Tacconi, L., Rios, M.T.S. and Wells, A. 2006. Justice in the forest: Rural livelihoods and forest law enforcement. Forest Perspectives No.3, Center for International Forestry Research (CIFOR), Bogor, Indonesia. 98p.

[2006年10月19日付け 貧者のための法施行強化？ ありえない! ]

Colfer, C.J.P. 2005. The Complex Forest: Communities, Uncertainty, \& Adaptive Collaborative Management. Resources for the Future, Washington D.C. 370p.

Colfer, C.J.P., Prabhu. R., Günter, M., McDougall, C., Porro, N.M. and Porro, R. 1999. Who Counts Most? Assessing Human Well-Being in Sustainable Forest Management. C\&I Toolbox 8. Center for International Forestry Research (CIFOR), Bogor, Indonesia.

Contreras-Hermosilla, A. 2000. The Underlying causes of forest decline. CIFOR Occasional Paper No. 30. Center for International Forestry Research, Bogor, Indonesia. 25p.

DeFries, R., Achard, F., Brown, S., Herold, M., Murdiyarso, D., Schlamadinger, B. and de Souza Jr, C. 2007. Earth observations for estimating greenhouse gas emissions from deforestation in developing countries. Environmental Science and Policy 10: 385-394.

de Jong, B.H., Masera, O., Olguín, M. and Martínez, R. 2007. Greenhouse gas mitigation potential of combining forest management and bioenergy substitution: A case study from Central Highlands of Michoacán, Mexico. Forest Ecology and Management 242: 398-411. 
Denman, K.L., Brasseur, G., Chidthaisong, A., Ciais, P., Cox, P.M., Dickinson, R.E., Hauglustaine, C., Heinze, E., Holland, D., Jacob, U., Lohmann, S., Ramachandran, P.L., da Silva Dias, D., Wofsy, S.C. and Zhang, X. 2007. Couplings Between Changes in the Climate System and Biogeochemistry. In: Solomon, S., Qin, D., Manning, M., Chen, Z., Marquis, M., Averyt, K.B., Tignorand, M. and Miller, H.L. (eds.) Climate Change 2007: The Physical Science Basis. Contribution of Working Group I to the IPCC Fourth Assessment. Report of the Intergovernmental Panel on Climate Change. p.541-584. Cambridge University Press, Cambridge, UK and New York, USA.

Ebeling, J. 2006. Tropical Deforestation and Climate Change: Towards an International Mitigation Strategy. University of Oxford, UK.

El Lakany, H., Jenkins, M. and Richards, M. 2007. Background Paper on Means of Implementation. Contribution by PROFOR to discussions at UNFF-7, April, 2007. Program on Forests (PROFOR). 50p.

Food and Agriculture Organisation of the United Nations (FAO) 2006. Global Forest Resource Assessment 2005: Progress toward sustainable forest management. FAO Forestry Paper 147, FAO, Rome, Italy. 320p.

Food and Agriculture Organisation of the United Nations (FAO). 2007. State of the World's Forests. FAO Rome, Italy. 144p.

Forner, C., Blaser, J., Jotzo, F. and Robledo, C. 2006. Keeping the forest for the climate's sake: Avoiding deforestation in developing countries under the UNFCCC. Climate Policy 6(3): 275-294.

Geist, H. and Lambin, E. 2002. Proximate Causes and Underlying Driving Forces of Tropical Deforestation. Bioscience 52(2): 143-150.

[2002年2月25日＼cjkstart森林の消滅－152の事例から一]

Gregersen, H.M., Contreras-Hermosilla, A., White, A. and Phillips, L. 2005. Forest governance in federal systems: An overview of experiences and implications for decentralization. In: Colfer, C.J. and Capistrano, D. (eds.) The Politics of Decentralization. Forests, People and Power. Earthscan, Sterling, London. p. 13-31.

Guariguata, M.R. and Ostertag, R. 2001. Neotropical secondary forest succession: Changes in structural and functional characteristics. Forest Ecology and Management 148:185-206. 
Gustafsson, L., Nasi, R., Nghia, N. H., Sheil, D., Meijaard, E., Dykstra, D., Pryadi, H. and Thu P. Q. 2007. Logging for the ark: Improving the conservation value of production forests in South-East Asia. CIFOR Occasional Paper no 48, Center for International Forestry Research, Bogor, Indonesia.

Holmes, D. 2000. Deforestation in Indonesia: A Review of the Situation in Sumatra, Kalimantan, and Sulawesi. World Bank, Jakarta, Indonesia. Hooijer, A., Silvius, M., Wösten, H. and Page, S. 2006. PEATCO2, Assessment of CO2 emissions from drained peatlands in SE Asia. Delft Hydraulics Report Q3943.

Humphreys, D. 2006. Logjam: Deforestation and the crisis of global governance. Earthscan, UK.

[2007年4月11日 国連森林フォーラム(UNFF):失敗への道?]

IPCC (Intergovernmental Panel on Climate Change). 2006. 2006 IPCC Guidelines for National Greenhouse Gas Inventories, Prepared by the National Greenhouse Gas Inventories Programme. Eggleston, H.S., Buendia, L., Miwa, K., Ngara, T. and Tanabe, K. (eds). Institute for Global Environmental Strategies (IGES), Japan.

Iskandar, H., Snook, L., Toma, T., MacDicken, K. and Kanninen, M. 2006. A comparison of damage due to logging under different forms of resource access in East Kalimantan, Indonesia. Forest Ecology and Management 237: 83-93.

Kaimowitz, D. 2002. Amazon deforestation revisited. Latin American Research Review 37(2): 221-235.

Kaimowitz, D. and Angelsen, A. 1998. Economic models of tropical deforestation - A review. Center for International Forestry Research (CIFOR), Bogor, Indonesia. 139p.

Kaimowitz, D., Byron, N. and Sunderlin, W. 1998. Public policies to reduce inappropriate deforestation. In: Lutz, E. (ed.) Agriculture and the environment: Perspectives on sustainable rural development, World Bank, Washington D.C. p 303-322.

Karousakis, K. 2007. Incentives to reduce GHG emissions from deforestation: Lessons learned from Costa Rica and Mexico. Organisation for Economic Co-operation and Development (OECD). Document: COM/ENV/EPOC/IEA/SLT(2007)1. 50p. 
Kauppi, P.E., Ausubel, J.H., Fang, J., Mather, A.S., Sedjo, R.A. and Waggoner, P.E. 2006. Returning forests analyzed with the forest identity. Proceedings of the National Academy of Sciences of the United States 103(46): 17574-17579.

Kleinn, C., Corrales, L. and Morales, D. 2002. Large area forest cover estimates in the tropics - The case of Costa Rica. Environmental Assessment and Monitoring 73(1): 14-40.

Kusters, K., De Foresta, H., Ekadinata, A. and van Noordwijk, M. 2007. Towards solutions for state vs. local community conflicts over forestland: The impact of formal recognition of user rights in Krui, Sumatra, Indonesia. Human Ecology 35(4): 427-438.

Lepers, E., Lambin, E.F., Janetos, A.J., DeFries, R., Achard, F., Ramankutty, N. and Scholes, R.J. 2005. A Synthesis of Information on Rapid Landcover Change for the Period 1981-2000. BioScience 55(2): 115124.

Mather, A. 1992. The Forest Transition. Area 24: 367-379.

Mather, A.S. 2007. Recent Asian forest transitions in relation to foresttransition theory. International Forestry Review 9(1): 491-502.

Mathews, E. 2001. Understanding the FRA 2000. World Resources Institute (WRI), Forest Briefing No. 1. 11p.

Mayers, J. 2006. Small-Medium Forestry Enterprises. The 'bestbet' for reducing poverty and sustaining forests? Paper presented at International Tropical Forest Investment Forum: Issues and Opportunities for Investment in Natural Tropical Forests. 26-27 April 2006, Cancun, Mexico.

Meijaard, E., Sheil, D., Nasi, R., Augeri, D., Rosenbaum, B., Iskander, D., Setyawati, T., Lammertink, M., Rachmatika, I., Wong, A., Soehartaono, T., Stanley, S. and O'Brien, T. 2005. Life after Logging: Reconciling Wildlife Conservation and Production Forestry in Indonesian Borneo. UNESCO and Center for International Forestry Research (CIFOR), Bogor, Indonesia. 345p.

[2005年1月31日＼cjkstart箱船なんだから、無茶はしないで］

Milledge, S.A.H., Gelvas, I.K. and Ahrends, A. 2007. Forestry, Governance and National Development: Lessons Learned from a Logging Boom in 
Southern Tanzania. Dar es Salaam, Tanzania: TRAFFIC East/Southern Africa, Tanzania Development Partners Group, Ministry of Natural Resources and Tourism. 252p.

Molnar, A., Scherr, S. and Khare, A. 2004. Who Conserves the World's Forests? Community-Driven Strategies to Protect Forests and Respect Rights. Forest Trends, Washington D.C. Available at: www. forest-trends.org

Murphy, D.J. 2007. Future prospects for oil palm in the 21st century: Biological and related challenges. European Journal of Lipid Science and Technology 109(4): 296- 306.

Nepstad, D.C., Veríssimo, A., Alencar, A., Nobre, C., Lima, E., Lefebvre, P., Schlesinger, P., Potter, C., Moutinho, P., Mendoza, E., Cochrane, M. and Brooks, V. 1999. Largescale impoverishment of Amazonian forests by logging and fire. Nature 398 (6727): 505-508.

Ostrom, E. 1990. Governing the commons: The evolution of institutions for collective action. Cambridge University Press, New York.

Ostrom, E. 1999. Self-governance and forest resources. CIFOR Occasional Paper No. 20. Center for International Forestry Research, Bogor, Indonesia.

Oyono, R., Ribot, J.C. and Larson, A.M. 2006. Green and Black Gold in Rural Cameroon: Natural Resources for Local Governance, Justice and Sustainability. Center for International Forestry Research (CIFOR), Bogor, Indonesia and World Resources Institute (WRI), Washington D.C.

Penman, J., Gytarsky, M., Hiraishi, T., Krug, T., Kruger, D., Pipatti, R., Buendia, L., Miwa, K., Ngara, T., Tanabe, K. and Wagner, F. 2003. Good Practice Guidance for Land Use, Land-Use Change and Forestry. IPCC National Greenhouse Gas Inventories Programme and Institute for Global Environmental Strategies (IGES), Kanagawa, Japan. Intergovernmental Panel on Climate Change. Available at: http:// www.ipcc-nggip.iges.or.jp/public/gpglulucf/gpglulucf_contents. htm.

Purnomo, H., Mendoza, G.A., Prabhu, R., Yasmi, Y. 2005. Developing multistakeholder forest management scenarios: A multi-agent system simulation approach. Forest Policy and Economics 7(4): 475-491. 
Reinhardt, G., Rettenmaier, N., Gärtner, S. and Pastowski, A. 2007. Rain Forest for Biodiesel? Ecological effects of using palm oil as a source of energy. WWF Germany, Frankfurt. 50p.

Ribot, J. 2002. Democratic decentralization of natural resources: Institutionalizing popular participation. World Resources Institute (WRI), Washington D.C.

[2002年10月15日＼cjkstart分権するなら民主化を］

Righelato, R. and Spracklen, D.V. 2007. Carbon Mitigation by Biofuels or by Saving and Restoring Forests? Science 317:902.

Rudel, T., Coomes, O., Moran, E., Acgard, F., Angelsen, A., Xu, J. and Lambin, E. 2005. Forest transitions: Towards a global understanding of land use change. Global Environmental Change 15: 23-31.

Setiono, B. 2007. Debt settlement of Indonesian forestry companies: Assessing the role of banking and financial policies for promoting sustainable forest management in Indonesia. Forests and Governance Programme No. 11/2007. Center for International Forestry Research (CIFOR), Bogor, Indonesia. 59p.

Setiono, B. and Husein, Y. 2005. Fighting forest crime and promoting prudent banking for sustainable forest management. The anti-money laundering approach. CIFOR Occasional Paper No. 44. Center for International Forestry Research, Bogor, Indonesia. 25p.

Skutsch, M., Bird, N., Trines, E., Dutschke, M., Frumhoff, P., de Jong, B.H.J., van Laake, P., Masera, O. and Murdiyarso, D. 2007. Clearing the way for reducing emissions from tropical deforestation. Environmental Science and Policy 10: 322-334.

Smith, J. and Scherr, S.J. 2003. Capturing the Value of Forest Carbon for Local Livelihoods. World Development 31(12):2143-2160.

[2002年10月21日 炭素の利益を住民に（上記の基礎となった報告 書)]

Smith, J., Obidzinski, K., Subarudi, S. and Suramenggala, I. 2007. Illegal logging, collusive corruption and fragmented governments in Kalimantan, Indonesia. In: Tacconi, L.(ed.). Illegal logging: Law enforcement, livelihoods and the timber trade. Earthscan, London. p. 91-109.

[2004年1月28日 賄賂も様変わり(上記の基礎となった論文)] 
Spek, M. 2006. Financing pulp mills: An appraisal of risk assessment and safeguard procedures. Center for International Forestry Research (CIFOR), Bogor, Indonesia. 86p.

Stern, Sir Nicholas. 2006. Stern Review: The Economics of Climate Change. Cambridge University Press, Cambridge, UK. [2007年1月12日＼cjkstart森林と気候変動に関する厳格な意見］

Stibig, H-J., Stolle, F., Dennis, R., and Feldkotter, C. 2007. Forest cover change in Southeast Asia - The Regional Pattern. JRC Scientific and Technical Reports, EUR 22896 EN - 2007.

Sunderlin, W.D. and Wunder, S. 2000. The Influence of Mineral Exports on the Variability of Tropical Deforestation. Environment and Development Economics 5(3): 309-332.

Tacconi, L. 2007. Deforestation, forests and livelihoods: Theory and narrative. Global Environmental Change 17:378-48.

UNFCCC (United Nations Framework Convention on Climate Change). 2001. Report of the Conference of the Parties on its Seventh Session, held at Marrakesh from 29 October to 10 November 2001. Addendum Part two: Action Taken by the Conference of the Parties, Volume I. [Marrakesh Accords, cf. paragraph 1 of the Annex to draft decision/CMP.1 (Land use, land-use change and forestry). Document: FCCC/ CP/2001/13/Add.1, p. 58] Available at: http://unfccc.int/resource/ docs/cop7/13a01.pdf

UNFCCC (United Nations Framework Convention on Climate Change). 2003. Land Use, Land-use Change and Forestry: Definitions and Modalities for Including Afforestation and Reforestation Activities under Article 12 of the Kyoto Protocol in the First Commitment Period: Options Paper on modalities for addressing baselines, additionality and leakage. Document: FCCC/SBSTA/2003/6. Available at:http:// unfccc.int/resource/docs/2003/sbsta/06.pdf

United Nations Security Council (UNSC). 2002. Final Report of the Panel of Experts on the Illegal Exploitation of Natural Resources and Other Forms of Wealth of the Democratic Republic of the Congo. United Nations Security Council (UNSC), New York.

Wily, L.A. 2004. Can We Really Own the Forest? A Critical Examination of Tenure Development in Community Forestry in Africa. Paper 
presented at the Tenth Biennial Conference, International Association for the Study of Common Property (IASCP), 9-13 August 2004, Oaxaca, Mexico.

Wright, R. 2004. Defining the China Market for Pulp, Paper and Board. Hawkins Right, London.

Wunder, S. 2000. The economics of deforestation. The example of Ecuador, Macmillan, St.Antony's Series, Houndmills, UK. 262p.

Wunder, S. 2003. Oil wealth and the fate of the forest. A comparative study of eight tropical countries. Routledge, London and New York. 432p.

[2003年9月5日「環境のための協調」]

Wunder, S. 2007. The efficiency of payments for environmental services in tropical conservation. Conservation Biology 21(1): 48-58.

[2007年8月6日「イイ奴は売れ残る?」]

Wunder, S. and Verbist, B. 2003. The impact of trade and macroeconomic policies on frontier deforestation. ASBL Lecture Note 13. World Agroforestry Centre, Indonesia. 


\section{付録一POLEX日本語版で紹介された本書の引用文献}

森林政策エキスパート(POLEX)メーリングリストは、国際林業研究センター の無料情報サービスとして1997年 7 月に開始され、日本語版は2001年12月 に開始されました(2007年 3 月までは藤間が、2007年4月以降は鷹尾が、和訳 を担当しています)。POLEXには、英語版、スペイン語版、フランス語版、インド

ネシア語版もあります。POLEXの受信を希望する方は、Ms. Ketty Kustiyawati $<$ k.kustiyawati@cgiar.org>に御希望の言語を指定して御連絡ください。過去の POLEXメッセージはCIFORウェブサイトで公開されています。

http;//www.cifor.cgiar.org/Publicaions/Polex/

本書の引用文献中、POLEX日本語版で紹介されたものを日付順に再録しまし た。

\section{2年2月25日＼cjkstart森林の消滅－152の事例から-}

152 snapshots of disappearing forests (Feb. 25, 2002)

熱帯林が減少している理由について、人々はそれぞれ時として相反する理由 を考えています。ある人々は、人口爆発と小規模農家による焼畑を非難していま す。また別の人々は、政府の森林政策の䛊りや大企業および大地主の活動を森 林減少の要因として重要視しています。森林減少について議論するためには、現 実に即した証拠が多数必要なのです。

Helmut Geist達は、「熱帯林減少につながる直接的な原因と背後要因 (Proximate Causes and Underlying Driving Forces of Tropical Deforestation)」 において、さまざまな地域からの実例を多数取りまとめました。著者達は、熱帯地 域での森林減少に関する152の研究例をみなおして、森林減少にはさまざまに 異なる原因がそれぞれ重要であることを示しました。ここで著者らが対象とした 地域とは、一つの集落から複数の州にまたがるまでの広がりをもつています。

実際、どの地域でも、農民は森林を切り開き、作物を植えたり牧草地にしたりし ていました。約半数の場合、商業的な伐採が森林減少に重要な要因で、移動耕作 は約 $40 \%$ の場所で重要な要因となっていました。牧場の造成は、ラテンアメリカ では重要な要因ですが、アジアおよびアフリカではそれほどではありません。然 料材の採集も各地にひろがっています。全体の約5分の2の場所で、貧困が森林 
減少につながっていました。また同じくらいの頻度で、強力な政府機関や私企業 が自分達だけのために、森林伐採を推進していることが森林減少を引き起こして いました。

森林減少を引き起こす背後要因としては、道路建設、換金作物や木材に対す る需要の増加、農業開発のための移住計画、援助による借款、土地利用権に関す る不適切な政策などが目立っていました。これらの背後要因は、熱帯地域すべて に共通のものですが、アフリカでは移住と援助による借款はそれほど重要ではあ りませんでした。多くの場所で、人の入植によって森林が切り開かれています。 しかし、高い人口増加率が森林減少を加速しているという証拠はありませんでし た。森林減少に関するほとんどの研究は、文化的もしくは技術的要因の影響に焦 点をあわせていました。

ここでみてきたことは、私達が熱帯林の減少についてどのような原因を考えよ うと、その事例が成立する場所を見つけることができるということです。それは私 達がどこに注目するかにのみかかっています。ほとんどの場合、熱帯林の減少は 一つの原因で起きているわけではありません。複数の異なる原因が組み合わさ つた結果として森林が減少しているのです。そのため、不適切な森林伐採を改善 するための統一的な政策はありえないのです。いずこの地域もそれぞれ、その地 域に特有のアプローチを必要としています。

今回、紹介したGeistとLambinの研究は、

http://www.geo.ucl.ac.be/LUCC/pdf/02_February_Article_Geist_.pdf からダウンロードできます(2008年 2 月現在)。

\section{2年10月15日 分権するなら民主化を}

\section{When you decentralize, democratize (Oct. 16, 2002)}

近年、少なくとも600国々が自然資源管理に関する地方分権化を果たしまし た。そして、その結果は悲喜こもごもです。地方分権により、それまでは森林に関 する政策決定に参加できなかった人達が参加できるようになったり、地方政府の 歳入が増加したり、その地域の人々が自分達の決定によってよりよい森林管理を 実施できるようになった実例があります。一方、まったく逆、つまり失敗例も山のよ うにあります。 
失敗例をとりあげて、中央政府は地方分権化を急速に進めすぎだと批判する 人たちがいます。しかし世界資源研究所(WRI)のJosse Ribotは、中央政府が 十分に地方分権をはからなかったことにより、そのような失敗が抢きたと反論し ます。彼は自身の著書「天然資源の民主的地方分権化、大衆参加による組織化 (Democratic Decentralization of Natural Resources, Institutionalizing Popular Participation)」のなかで、地方分権は民主的な意志決定過程を必要と するとともに、中央政府から地方政府に主だった決定権が委譲される必要がある と述べています。また、中央政府はいったん地方に委譲した権限を取り返しては ならないとし、さらには地方分権が機能するようになるためには時間がかかるこ とを認識する必要があるとしています。

Ribotは、ボリビア、ブラジル、カメルーン、中国、インド、インドネシア、マリ、メキ シコ、モンゴル、ニカラグア、セネガル、南アフリカ、タイ、ウガンダおよびジンバブ エの15力国で事例研究を行いました。これらの国々の多くでは、中央政府は数々 の矛盾と混乱を引き起こしました。中央政府はやっかいな業務と劣化した自然資 源を地方政府に押しつける割に、魅力的な業務扔よび豊かな資源は地方分権の 対象にしないという傾向があります。また地方政府には自然資源を適切に管理す る能力が無いという批判を行います。かし地方政府に欠けているものが何であ って、どのように改善すべきかという点について具体的な指摘をしないことがま まあります。

地方政府もたいがいなものです。彼らは必ずしも有権者を代表する存在ではあ りません。また自然資源を過剩に利用してしまう傾向があります。そして、特定の 集団の利害にのみ貢献します。

地方分権が抱えるこのような問題を解決するには、評価と修正を実施するため の透明なシステムが必要であることから、Ribotは次のような提言をしています。 中央政府は地方政府が最低限従うべき環境基準を設定する必要がある。中央政 府はまた、法律の遵守、民主的な意志決定機構、予算の透明性、そして個人とくに 女性や社会的弱者の権利を保障する必要があります。一方、地方政府は、国家の 枠組みに従いながら、彼がまかされた自然資源を適切に管理できるようになる必 要があります。このような過程をへた地方分権によってはじめて、大面積かつ長 期間にわたる、民主的な自然資源管理が可能となるのです。

今回、紹介した書籍は下記から購入を申し込むことができます。

http://www.wristore.com/demdecofnatr.html 


\section{2年10月21日 炭素の利益を住民に}

\section{Carbon markets for the poor (Oct. 21, 2002)}

今週、インドのデリーで始まるCOP8(注1)から、地球温暖化ガス排出削減に 関する議論は新たな局面に入ります。前回、モロッコのマラケシュで開催された COP7において、開発途上国での新規植林および再植林(注2)が京都議定書 12条で規定されるクリーン開発メカニズム (CDM、注3)の吸収源として認められ ました。2008年から2012年にかけての第1約束期間では、新規植林、再植林し かCDMとして認められていませんが、第2約束期間以降は森林保全や低インパク 卜伐採施業等の森林の持続的な利用も、CDM事業として認められる可能性が出 てきました。

国際林業研究センターのJoyotee Smithとフォレストトレンズ(注4)のSara Scherrは、「森林の炭素と農村の生計 (Forest Carbon and Local Livelihoods)」と して、CDMプロジェクトが農村(地方)の人々の生計に与える影響について取りま とめました。同書は、大規模植林、小規模植林、アグロフォレストリー、天然更新、 住民共同体による森林管理および厳正な森林保全のそれぞれについて、CDMが 地域の人々の生計に与える利益とリスクに関する評価を行っています。CDMプロ ジェクトの形態の違いにより、利益とリスクも異なります。しい、規模が小さいほ ど、また住民の参加度が高いほど、地域住民の生計が向上する傾向があります。 小規模なCDM森林プロジェクトではより大規模なプロジェクトに比べて、環境 への好影響が大きく、リーケッジ(注5)のリスクが小さくなります。小農家や共同 体によるCDMプロジェクトは経済的に実現性の高いものですが、大規模プロジ エクトに比べるとコスト高の傾向があります。これは、多数の小規模農家による事 業をモニタリングするには費用がかかること、そのようなプロジェクトは多くの場 合、生産性の低い土地で実施されていることによります。そのため、小規模生産者 にもCDMプロジェクトによる利益をもたらしたいと考えるなら、発展途上国政府 は小規模生産者達が大規模プロジェクトに対して競争力を持ちうるよう配慮する 必要があります。

JoyoteeとSaraは、CDMプロジェクトの実施にあたっては、地域の人々が従来持 っていた森林および土地利用に関する権利が侵害されないようにすべきである と強調します。CDMは、小規模な植林活動、アグロフォレストリー、そして森林再 生をも対象にする必要があります。また、規模に応じて簡略化された報告システ 厶を採用する必要があります。発展途上国政府は、地域の人々の土地および森林 
利用に関する権利を保証し、CDMに関する普及教育およびプロジェクト形成へ の支援をすることで、国民に利益をもたらすことができます。

クリーン開発メカニズムは、その名が示すとおり環境に悪影響を与えることなく 開発に貢献すべきです。JoyoteeとSaraは、CDMプロジェクトの進むべき方向を示 しました。

今回、紹介した報告書 (pdf) は、下記からダウンロードできます。 http://www.cifor.cgiar.org/Publications/Detail?pid=1086

注1:気候変動枠組条約第8回締約国会議

注2: 新規植林 (afforestation), 再植林 (reforestation)

注3:クリーン開発メカニズム(Clean Development Mechanism)

注4:Forest Trends 保護区以外の森林保全に市場ベースで取り組む非営利団体 http://www.forest-trends.org

注5:leakage; プロジェクト実施によりプロジェクト対象地域外における炭素放出 が増加すること。

\section{3年9月5日「環境のための協調」}

\section{Adjusting our environment (Sep. 5, 2003)}

今回のPOLEXは、地下資源採掘に対する開発援助と森林保全に関する研究を 紹介します。

ほとんどの銀行は、直接の儲けが見込まれる事業に対して融資をおこないま す。しかし、世界銀行や国際通貨基金は、一般的な国家予算に対しても融資をお こないます。その代わり、融資の条件として国家の政策変更を要求することがあり ます。この国家政策の変更は、為替レートの変更、国家予算、開発計画、歳出方式 等に影響を与えるものです。

世界銀行は、開発プロジェクトに融資する際には、そのプロジェクトが環境に与 える影響について事前に評価することになっています。いし、政策変更に対す る融資(構造調整融資)については、構造調整の結果が環境に及ぼす影響に関す る評価は行われません。一方で、世界銀行の構造調整融資による経済活動の変 化は、世界銀行による個別の森林セクターへの融資プロジェクトよりも、森林に与 
える影響が大きいことがあります。そのため、世界銀行の新しい森林セクター支 援政策に対して、多くの政府機関、NGO、その他の団体は、構造調整が森林に与 える影響をも評価するべきであると提案しています。世界銀行も、構造調整が森 林に与える影響が大きいことを認めています。しかし、構造調整はすべての政策 分野を包括しているため、森林部門への影響だけを重視することは、あまり適切 でないという立場のようです。

世界銀行は現在、構造調整支援のための政策を修正しつつあります。世界銀行 のホームページ上に、修正案を公開し、広く意見をつのつた後、10月に修正案を 理事会に提出する予定です。この修正案では、世界銀行は、その融資によって目 指している構造調整が環境に与える影響に配慮すべきであるが、公式な環境影 響評価は必要としないというものになりそうです。このように、一見矛盾する提案 になるのは、(経済全体を対象とした)構造調整が環境に与える影響を評価する ことが、あまりにも複雑で困難なことによります。確かに、その影響は、間接的なも のですし、測定することが困難なものです。

CIFORのSven Wunderが最近出版した書籍「石油利権と森林の運命 (Oil Wealth and the Fate of Forests)」は、構造調整が環境に与える影響を評価でき ることを示した具体例となりました。Wunderは、石油をはじめとする地下資源の 輸出増大が、為替レート、国家予算、そして消費動向に与えた変化、そしてそれら が森林減少に与えた影響を、カメルーン、エクアドル、ガボン、インドネシア、メキ シコ、ナイジェリア、パプア・ニューギニア、ベネズエラの事例から取りまとめまし た。Wunderが見いだした結果は、構造調整が環境に与える影響について、各国 に共通するものでした。

貨幣価值(為替レート)が下がると、森林の減少が促進します。増加した政府歳 入が都市開発に割り当てられると、森林の破壊は減少します。一方、これが農地 開発、移住政策、森林地域を横切る道路の建設等に支出された時には、森林の減 少が促進します。南米諸国では、国民経済の向上により食肉への需要が増大し、 森林の牧場への変換が進みました。

Wunderの研究は、世界銀行が構造調整融資を実施するにあたり、環境への影 響を評価することは可能であること、また評価すべきであることを示しています。 また、世界銀行だけでなく、国際通貨基金も、同様に環境への影響を検討するこ とが必要であると言えるでしょう。幸いなことに、世界銀行が検討中の構造調整 政策の指針では、環境影響評価を取り上げる方向で議論が進められています。 
今回、紹介した書籍は、アマゾン・ドット・コム(http://www.amazon.co.uk)で、購 入することができます。

世界銀行の構造調整政策案については、下記ホームページからダウンロードで きます。

http://www 1.worldbank.org/operations/OP860Consultations/ EnglishVersion/1OPBP8.60public06-06-02pc.pdf

今回のPOLEXの翻訳に当たっては、世界銀行に勤務しておられた窪田様に、手 伝って頂きました。記して感謝します。

\section{4年1月28日 賄賂も様変わり}

Bribery just isn't what it used to be (Jan. 28, 2004)

今回のPOLEXは、インドネシアの地方分権によって、違法伐採とそれにまつわ る賄賂がどのように変わったかに関する研究を紹介します。今回紹介する論文 は、最近発行されたInternational Forestry Reviewの違法伐採特集号に掲載さ れたものです。

林業会社は、単に伐採権を得るためだけに、污職官僚の買収をおこなう気はあ りません。もしそれだけなら、費用対効果の点で割高になるからです。しかし、贈 賄によって、脱税、許認可手続きの簡略化、伐採基準の無視などが可能になると したら、贈賄は会社の収支にみあうものになるのです。

スハルト大統領が君臨していた頃、インドネシアの森林企業は、伐採権を得る ために多額の賄賂を支払う必要がありました。そして賄賂によって伐採権を得た 企業も、伐採に関する法律におおむ拉っていたのです。一方、森林官達は、伐 採業者が持続的森林経営のための法律に従わなくても、それを無視しがちだっ たのです。というのは、業者の違法行為を指摘するよりも、合法的に伐採がなされ ていると見なすことで、より多くの伐採税を徵収することが可能だったからです。 スハルト独裁体制は、自分たちの利益を満たすために十分な権力をもっていた のです。

スハルト大統領による独裁時代が終わり、インドネシアは地方分権の時代に入 りました。そして行政だけでなく污職も地方分権が進んでしまいました。林業省 は、木材関連企業に対する行政的指導の困難さに直面しています。地方政府は 
独自の伐採権を認可するようになり、伐採権の許認可を受けない人々が、伐採を 実施するようになりました。その結果、多額の贈賄も納税も必要と感じない企業 が多くなりました。

違法伐採や脱税の摘発によって、懲役や罰金刑を科せられることは、ほとんど ありません。しかしながら、違法行為が摘発される危険をさけるため、かなりの伐 採企業が、地方政府役人、軍関係者、警察官等に賄賂を払つています。賄賂の額 は、以前よりも少額になり、より多くの人に分配されているようです。企業が賄賂 に費やす金額と政府の税収はともに小さくなり、違法伐採の対象となる森林は増 加しています。

Joyotee Smith他による論文、「インドネシア、カリマンタン島の違法伐採、共謀 する污職と分断された政府」は、違法伐採とそのための污職が地方分権によっ てどのように変わってきたかを、東カリマンタン州(インドネシア領ボルネオ島東 部)の3つの郡で、調査しました。上で述べたような変化は、中央集権から地方分 権へ移行する際にありがちなものと、Smith達は考えています。伐採権を得るため に贈賄をおこなうよりも、伐採に関する法律を破る傾向が高まるため、地方分権 により污職総額が増えることは無いようです。

地方分権化による混乱に直面している人の中には、過去の強権体制を懐かし がる人もいます。しし、後戻りはできないのです。地方分権と民主化は推進され なければなりません。民主化の過程でおきる污職の䒤延を解決するには、さらな る民主化しかないのです。社会的な圧力があれば、政府機関の透明性と説明責 任を高めることができるでしょう。もちろん時間と多大な努力が必要ですが、でき ないことは無いのです。嘆くのはやめて、秩序をつくりあげましょう。

\section{5年1月31日＼cjkstart箱船なんだから、無茶はしないで}

\section{Log gently in Noah's Ark (Jan. 31, 2005)}

森林の伐採は、多くの鳥、サル、コウモリ、ヤマネコのように保護が望まれている 多くの動物種に影響を与えます。注意深い伐採により、動物たちに与える影響を 小さくすることができるはずです。Erik Meijaad達は、ボルネオ島そして東南アジ アの熱帯林において、伐採が野生動物に与える影響、そして野生生物を保全につ ながる伐採について、取りまとめました。

伐採は、森林を変えます。林道は、森林を小さなパッチに分断します。動物によ 
っては、細い道ですら渡ることができないものがいます。伐採により、個体数が多 くなる動物もいるのですが、逆に少なくなる動物もいます。また動物達が利用で きる食料も変化するのです。動物の巣があった樹木がきりたおされることがあり ます。太陽の光が直接地面に届くようになり、土や下草が乾燥し熱くなります。伐 採後に残された枝葉が溜まり、乾燥した森では、火災が起きやすくなります。地面 表層の栄養のある土は洗い流され、川に流れ込み、環境を変えていきます。そし て、猟師達が森林に入り込みます。

動物に影響しない伐採などないのですが、森林を細かく分断しないこと、伐採 後の狩猟を制限することで、全部とは言わないまでも多くの動物の生存が容易に なります。特別な種類の餌しか食べない動物は、伐採の影響をより強く受けます。 昆虫もしくは果実しか食べない動物は、雑食性の動物にくらべ、伐採後に食料難 に陥りやすいのです。また、地上か樹上のどちらかでしか生活していない動物は、 両方を行き来できる動物よりも、伐採による影響を強くうけます。広い範囲を移動 してくらす肉食獣も伐採による影響を強く受けるものの一つです。清流を好むサ カナやカエルは、土砂が流れ込んだ川では生活できません。同じように、多くの動 物が伐採による影響を受けます。

動物達を守るためMeijaard達は、伐採業者に次のような提言をしています。森 林の分断をできるだけ小さくするように林道を計画的に配置する。猟師を森に入 れない。伐採後の下刈りをやめツル植物や下草を残す。土壌を荒らさないように する。川岸や池、集落跡、塩泉(動物たちが塩をなめにくる)などの近くは伐採をお こなわずに残す。また、動物の住処であり商業的価値がない)うろのある木、果 実をつける種類の木(とくにイチジク科の樹木)は伐採せず、古い切り株にも手を つけない。これらにより、すべての動物が守られる訳ではありません、しかし、動物 たちに与える影響を小さくすることができるはずです。

今回、紹介した書籍、Meijaard E. et al. 2005. Life After Logging, Reconciling Wildlife Conservation and Production Forestry in Indonesian Borneo, Bogor, CIFOR, のPDFファイル (2.5MB) は下記からダウンロードできます。www.cifor. cgiar.org/scripts/newscripts/publications/detail.asp?pid=1663 


\section{6年10月19日付け 貧者のための法施行強化？ ありえない!}

\section{Pro-Poor Forest Law Enforcement? Not Likely. (October 19, 2006)}

2001年9月11日、貴方はどこで何をしていましたか？POLEX筆者(フランシ ス・セイモア)はバリにいて、第一回森林法の施行に関する東アジア閣僚会合に 出席していました。（訳者藤間は、ボゴールでニュースを見て呆然としていまし た。)アジアで始まり世界に広がった森林法を強化する取り組みは、違法伐採や 森林に関係する犯罪との戦いに、国際的な注目を集める助けとなりました。違法 伐採や森林犯罪は発展途上国の政府歳入を奪うものであることから、貧困撲滅 を目的とする開発援助機関は、森林法施行強化を貧困撲滅戦略の一つとして取 り上げるようになりました。

それから5年、Marcus Colchesterと共同研究者達は法施行強化が農村部の 人々の生活にどのように影響したのかに関する総説を出版しました。「森林での 正義：農村の生計と法施行強化」は、ボリビア、ホンジュラス、ニカラグア、カメル ーン、インドネシア、カナダで実施した事例研究の結果を要約しています。それぞ れの国におけるさまざまな条件の違いをこえて、共通の結果が見いだされまし た。

森林法は、貧しい人が森林から得ている収入を違法なものと決めつけたり、小 規模な森林利用に対しても非常に煩雑な手続を要求したりすることがあります。 森で暮らす貧しい人々は、しばしば大きな犯罪ネットワークに誘惑されてしまい ます。というのは、違法な活動はその地方の政治に深く入り込んでいるため、より 大きな力を持っている森林事業者ではなく貧しい人々に対する取り締まりが強 化されるからです。その結果、闇雲な法施行強化は貧しい人々の共感をえるより も、すでにある不公正をより強くすることがあるのです。

住民の権利を守るための法律は、脆弱で不明瞭であったり、無視されたりしが ちです。しかし公正な森林ガバナンスに対する社会的要求の増大により、先住民 や地域社会の森林資源に対する権利を認める進歩的な法制度の整備が進んで きました。

貧困撲滅を目標にするなら、短絡的な森林法強化が貧しい人々に予想外の不 利益をもたらす可能性を認識し、包括的な法制度整備に対する社会的要求を醸 成する組織や機関による取り組みを強化することが大切です。

今回紹介したのは、下記の書籍です。 
Colchester M. et al. 2006. Justice in the forest: Rural livelihoods and forest law enforcement. CIFOR. 98pp.

無料電子ファイルを下記からダウンロードすることができます。 http://www.cifor.cgiar.org/Publications/Detail?pid=1965

\section{7年1月12日付け＼cjkstart森林と気候変動に関する厳格な意見}

\section{Stern messages on forests and climate (January 12, 2007)}

2006年11月にケニアのナイロビで開かれた、気候変動枠組条約第12回締約 国会議(COP12)および京都議定書第2回締約国会合(COP/MOP2)では、森林 に関わる議論が目立ちました。気候変化に対する適応において森林が鍵となる という認識が高まったことは、ナイロビ会議の重要な成果の一つです。しかし森 林が重要視されたのは、温暖化ガスの排出削減戦略としての「森林減少の回避」 に関する討議によるようです。

このような討議がなされたのは、気候変動の経済的側面に関する解析(スター ン・レビューと呼ばれる)を2006年10月に英国政府が公表したことも影響してい ます。スターン・レビューは、「森林破壊の防止」を気候変動に対する国際的取り 組みにおける四つの最重要課題の一つとして強調しています。これは毎年世界 中で排出されている温暖化ガスの約 2 割が森林破壊によるという推定によりま す。そしてその量は、燃料を大量に消費している輸送業界が排出している量より 多いのです。

スターン・レビューは、森林破壊の防止による温暖化ガスの排出量削減は、相 対的に安いものであると結論します。土地利用の変化による温暖化ガスの排出 の70\%を占める8つの国での研究は、森林破壊を止めた場合の機会費用を年当 たり50～100億ドル程度と見積もっています。つまり、森林破壊の防止による二 酸化炭素ガス排出削減コストは 1 トンあたり 1 ～ 2 ドル程度で、その30倍に達す ることもあるとされる化石燃料による排出削減コストに比べ、非常に小さなもの です。

スターン・レビューが森林破壊の防止を温暖化ガス排出削減のための魅力的 な戦略と結論した別の理由は、新しい技術を開発しなくても実施可能なことによ ります。しい、森林破壊の防止が気候変動対策に効果的であると認めるために は、制度および政策上の大きな課題を解決する必要があります。これらの課題に 
は、森林に関連する権利を明らかにすること、法律の施行を強化すること、そして 堅牢なシステムに守られた既得権益を打ちやぶること、等が含まれます。取り組 みを成功に導くには、地域の状況に応じたインセンティブの確立や、取引費用の 最小化なども必要です。

森林政策に携わる人久は、気候変動の議論において森林問題が注目されるの は歓迎すべきことながら、組織的および政策的課題の解決に必要な「技術」が継 続的取り組みを必要とする複雑なものであり、決してタダではないことを知って います。森林破壊の原因を取り除くため、気候変動への適応としてまた再生可能 なエネルギー源としての森林資源を配置するために、最良の情報と解析を効率 的、効果的そしてなにより公平な方法で提供することが、森林に関わる研究者の 責務なのです。

今回、紹介した「スターン・レビュー」の日本語版概要は英国大使館ウェブサイト からダウンロードできます。

http://www.uknow.or.jp/be/environment/environment/07.htm

気候変動枠組条約第12回締約国会議(COP12)、京都議定書第2回締約国会合 (COP/MOP2)

については、下記に会合の概要が掲載されています。

http://www.env.go.jp/press/press.php?serial=7721

\section{7年2月15日付け 森林と貧困:そんな単純な話ではない!}

\section{Forest and Poverty: No Easy Generalizations (February 15, 2007)}

「貧困が森林破壊を引き起こす。」とか、「森林破壊が貧しい人々を傷つける。」 と、単純に言い切る人は有罪です。世界銀行の新しい報告書「熱帯林の環境、農 地の拡大、貧困の削減は、論争の対象か?」で、Ken Chomitzは「そんな簡単な話 ではない。」と述べています。

Chomitzは、彼自身そしてCIFORを含む他の多くの研究による膨大なデータと 解析をとりまとめています。様々な要因により森林被覆と貧困との間に単純な関 係が無いことを、多くの研究が繰り返し示しています。例えばこの報告書では、貧 困者率と貧困者密度を明瞭に区別します。森林が多いところほど貧困者率が高 
い傾向があります。しかし、森林が多い僻地では人口密度が低いため、実際に貧 困な人々の数は相対的に少ないのです。

さらに僻地では市場や公共サービスへのアクセスが悪い傾向があり、森林を別 の土地利用に転換して得られる利益や、貧困から抜けだすための経済活動の障 壁となっています。このように、貧困者率が高いことと森林破壊が少ないことは、 その両者に因果関係があるというよりも、僻地であるという条件によると理解す る方が有効です。

Chomitzは、価格、貨金、技術、土地利用権、などの変化が、森林と貧しい農民に 与えるインパクトについて知られていることを要約してします。多くの場合、その 答えは、「時と場合による」。その他の要因は、それほど不明瞭ではありません。た とえば、僻地に道路を延ばし、道を良くすることによって、貧しい人々の収入が増 え、森林が失われます。

Chomitzの報告書は、森林と農地がモザイク状に混在するところ、森林と農地 の境界や農地開発が議論されているところ、農地開発がおよんでいないところ、 のそれぞれに政策的提言をおこなっています。森林保全と貧困解消を両立させ る方策や、森林保全と貧困解消の間にトレードオフがある場合の施策は、制度や 統治を改善というところに落ち着きます。そして、林地と森林資源に関する権利を 明確にして守ることの必要性、経済的な手法が直接の動機付けや合理的な規制 に与える可能性について、繰り返し指摘します。

Chomitzは、森林破壊と貧困の両方を減らすための道具として、炭素基金に大 きな可能性を認めています。気候変動回避のため先進工業国は、貧しい農民が 森林を他の土地利用に用いないことに対し、お金を出すことを希望するはずで す。追加的な利益として、生物多様性の保全も期待できます。このような資金提供 のための国際的合意を形成する議論は非常に難しいものです。しし議論の結 果として、森林破壊を止めるための国家政策が貧しい人々を傷つけるのではなく 助けようにすることこそが、本当の課題です。

多くの国際援助機関は貧困削減に活動目的の焦点を絞りつつあり、森林保全 と貧困削減が常にともに進むと期待する人を喜ばせています。Chomitzの報告 は、森林と貧困の関係はそれほど単純ではないことを、思い出させてくます。

今回、紹介した、Chomitzの報告は、下記からダウンロードできます。

http://www.worldbank.org/tropicalforestreport/ (click on "Full Text"). 


\section{7年4月11日付け 国連森林フォーラム (UNFF) : 失敗への道? \\ The UNFF: Set up to Fail? / April 11, 2007}

国連森林フォーラム(UNFF)第7回会合は2007年4月16-27日にニューヨーク で開催され、世界中から出席者が集まります。今回の会合では(2015年まで)今 後8年間の「多年度作業計画」の採択や「世界の森林に関する法的拘束力を伴 わない文書」についての合意が予定されています。もしかしたら、今回がUNFFに とりその存在意義を示せる最後のチャンスかもしれません。もし、今回もまた UNFFが世界の森林の多種多様な危機に取組む重要なフォーラムであるというこ とをはっきりと示せなければ、もう次回はないかもしれないと多くの人々は心配 しています。

しかし、デビッド・ハンフリーズの新著を読むと、今回もニューヨークでの成果 に大きな期待は持てなくなってしまいます。ハンフリーズは新著「ログジャム：森 林減少と地球政治の危機*」で、UNFFなど森林減少に関する政府間の取組みは 現在の世界経済秩序を根本的に変えることができず失敗に終わるであろう、と主 張しています。

* "LogJam: Deforestation and the Crisis of Global Governance" by David Humphreys, Earthscan, 2006

著者によれば、森林の乱開発を拡大させる鍵となっているのは「新自由主義」と いうイデオロギーなのです。新自由主義とは国際貿易と投資のルールを牛耳り、 企業利益の追求のために公的な制度を変えてしまうものなので、政策改革によ って森林減少を食い止めようとする努力はことごとく阻止されてしまうのです。例 えば、「森林法施行、ガバナンス及び貿易に関する欧州連合行動計画(EU-FLEGT Action Plan)」は、世界貿易機構(WTO)のルールに抵触しないために二国間の 任意の許可制度に限定されています。世界銀行は新自由主義の原理を信奉し債 務国である熱帯林諸国の自由化、民営化、構造改革を図るので、同じ世界銀行に よる森林保護推進の取組みはなかなからまくいきません。著者は、森林管理協議 会(FSC)など、公的機関ではできない部分を市場原理で補う取組みには賛同し ていますが、規制緩和と民営化による改革という新自由主義的な方法を最初か

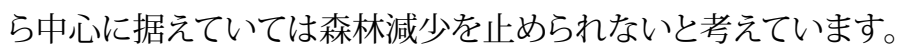

「ログジャム」ではUNFFと二つの前身、「森林に関する政府間パネル (IPF)」と 
「森林に関する政府間フォーラム (IFF)」についても章を割いています。ここでは 各会合と決定事項を年代順に紹介して、なぜ法的拘束力を持つ森林条約が合意 に至らないかを解説しています。筆者は、市民団体などのグループが交渉に影響 を与える場としてのUNFFの「マルチステークホルダーによる対話」に対して批判 的です。また、メンバー国政府が決定事項の報告や実行をきちんと行わないこと を強く批判しています。さらに、筆者によれば、UNFFはいまだに森林関係の他の 制度に対してリーダーシップを発揮し進路を示しているとはいえません。UNFFの 出席者がこれらの問題を少しでも改善することに関心を向けてくれるといいので すが。

この本は楽観的な話で締めくくられています。筆者は「グローバリゼーションの 民主化」という展望を示しました。そこでは、私企業の経済活動に対して公的な規 制を行うことも新たな制度により可能となります。そして、すでに筆者はこれの実 現に向けた動きの芽を見出しています。さて、今の段階では、「ログジャム」はニュ ーヨークへと向かうUNFFの出席者が機内で眠気を吹き飛ばす格好の読み物と なるでしょう。

"LogJam: Deforestation and the Crisis of Global Governance" by David Humphreys, Earthscan, 2006

今回、紹介した書籍は下記、出版社ウェブページから購入できます。

http://shop.earthscan.co.uk/ProductDetails/mcs/productID/707

\section{7年8月6日付けイイ奴は売れ残る?}

\section{Should good guys finish last? (August 6, 2007)}

「環境サービスへの支払い (Payment for Environmental Services, PES)」 というと、森林保全の新しい手段であり、環境の世話をしてくれる貧しい人久 に報酬を与えることだと、漠然と考えられてきました。しかし、CIFORの科学者 Sven Wunderは、PESでは保全の効率性と公平性の両立が難しいと、最近 Conservation Biology誌に発表したエッセイで警告しています。PESの枠組みに は、実際に便益を増加させられる効率性と同時に、社会的に受け入れられるため の公平性も求められるのです。

PESの枠組みでは、明確に定義された環境サービスを売買する、当事者間の自 
発的かつ任意の合意が必要です。この合意により、土地所有者が保全的でない 土地利用を断念したために失う利益を他の利害関係者が補償し、土地所有者の 私的な利益と他の利害関係者の利益の間の溝を橋渡しします。例えば、ある流域 下流での飲料水や水力発電、治水などのサービスの受益者は、上流の森林を保 全し土壌浸食を制御してこれらのサービスを守ってもらうためには、その土地所 有者への支払いを惜しまないでしょう。

効率を最重要視すると、PESは環境への脅威が明らかに発生しているところに しか適用できなくなり、公平感を損なうことになるだろうとWunderは予想してい ます。もしあるコミュニティが森林と調和して生活していれば、その模範的な環 境管理に対して報酬を支払うのが公正に思えます。しかし残念ながら、その報酬 で新たな保全は「買え」ず、さらなるサービスも生まないので、買い手はなかなか 見つかりません。それに対し、すでに森林を伐り開いてしまった牧場主なら、もし PESの報酬が森林を牧場にして得る利益よりも良さそうなら態度を変えるかもし れません。

期待利益が森林以外の土地利用でもさほど高くない場合、PESはたいてい成 功するだろうとWunderは考えています。かし、森林を農地にして大豆やヤシ油 など高価商品を生産しようというようなところでは、農地にしないで保全したくな るほどの補償をPESで出していたら資金はたちまち底をついてしまいます。

取引費用が高いとPESによる貧困軽減の可能性を狭めてしまいます。取引費用 が最も高くなるのは、小規模所有者が大勢いて、所有権は弱く、情報やサービス の提供費用が高い場合だとWunderは述べています。このような場合、PESを開 始するための高い初期費用をドナーは援助すべきだとWunderは考えます。この ような場所ではへクタール当たりの運転費用は十分に低いので初期投資も見合 います。

気候変動に関して現在「森林減少・劣化に由来する排出の削減(Reduced Emissions from Deforestation and Degradation; REDD)」が論じられている中 で、Wunderの結論はまさに時機を得たものです。このような支払い方法は気候 变動と森林関係の両方の問題解決に資するかもしれませんが、同時に効率か公 平かといら厳しい選択も突きつけます。PESの報酬を受ける最適な対象者は、貧 しく森林に大した危害も与えられない環境的に穏健なコミュニティではなく、潤 沢な資本でチェインソーを買いまさに伐採に取り掛かろうとしている連中なので す。これを公平といえるのでしょうか? 
今回、紹介した文献は：

Sven Wunder (2007), The Efficiency of Payments for Environmental Services in Tropical Conservation, Conservation Biology 21 (1), 48-58.

Wunderの論文の無料コピーを御希望の方はMs. Ligia Pereira <L.Pereira@ cgiar.org>に御連絡ください。この論文は下記からもダウンロードできます。 http://www.blackwell-synergy.com/doi/full/10.1111/j.15231739.2006.00559.x?prevSearch=allfield\%3A\%28wunder\%29

CIFORはPESに関する研究と情報提供を積極的に行っています。 http://www.cifor.cgiar.org/pes/_ref/home/index.htm 


\section{Forest Perspectives Series}

1. Fast-Wood Forestry: Myths and Realities. 2003.

Christian Cossalter and Charlie Pye-Smith

クリスチャン・コサルター、チャーリー・パイ・スミス著

太田誠一、藤間剛監訳. 2005.

早生樹林業一神話と現実一

2. Forests and floods: Drowning in fiction or thriving on facts? 2005.

CIFOR and FAO (available in Indonesian, Chinese and Vietnamese)

3. Justice in the forest: Rural livelihoods and forest law enforcement. 2006.

Marcus Colchester et al.

4. Do Trees Grow on Money? The implications of deforestation research for policies to promote REDD 2007.

Markku Kanninen, Daniel Murdiyarso, Frances Seymour, Arild Angelsen, Sven Wunder and Laura German

\section{CIFORと日本}

CIFORの活動に対して日本政府開発援助(ODA)による支援がなされています。 ODAによる活動資金の拠出に加え、日本人理事による意思決定への参加、派遣研 究者による研究プロジェクトの実施等がなされています。

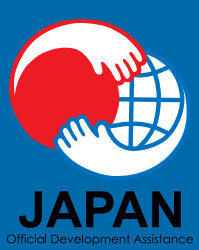

CIFORは、アジア地域における持続可能な森林経営の実現を目的に ヨハネスブルグ・サミット（WS S D ) のタイプ 2 プロジェクトとして開始 されたアジア森林パートナーシップ（AFP）の事務局として、日本の国 際協力と連携をとった活動を実施しています。AF P ホームページ

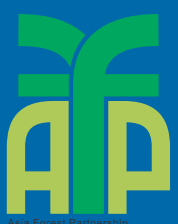
http://www.asiaforests.org/

CIFORは、日本との協力関係を強化することにより、熱帯林の持続的利用と熱帯林に依存して暮ら す人々の生活の向上にさらに貢献できるようになることを期待しています。 
森林減少と森林劣化は、気候变動および現在世界全体の炭素排出の5分の1を土地 利用变化に由来する排出が説明することと関連して、温暖化ガスの重要な排出源とし て認識されている。それゆえ、現存する森林を維持することは、最も経費のかからない 気候変動緩和策として、再び注目されている。発展途上国における森林減少と森林劣 化に由来する排出の削減が、2012年に終わる京都議定書に続く地球環境保護の枠組 の一要素として、現れてきた。

本書は、森林減少と森林劣化を進める主な要因、結果としておこる炭素放出を減ら すのに有効な政策選択 (オプション)を、要約する。本書は、現在の森林減少速度と森 林からの炭素放出のモニタリングとベースラインの確立に関する問題点を、再検討す る。森林減少と劣化の直接および潜在的な原因に関する研究による知見は、REDD政 策を形成するための基礎を提供するとともに、関連する難題を強調する。政策は様々 に局地的な状況を扱い、経済、規制、統治の改革を含める必要があると、本書の分析は 示唆する。本書の結論は、REDDを実施する新しい政策に対する提言である。

森林の展望 (Forest Perspectives) は、主要な森林問題に関する考察と討論を促進 するために出版されている。森林に関する国際的な対話と情報交換を奨励すると いうCIFORの公益業務の一環として、出版されている。本書の電子版はCIFORのウ エブサイト (www.cifor.cgiar.org) からダウンロードできる。 